\title{
GLOBAL DEVELOPMENT OF GREENHOUSE GAS EMISSIONS IN THE WASTE MANAGEMENT SECTOR
}

\section{Christoph Wünsch * and Robin Kocina}

Institute of Waste Management and Circular Economy, Department of Hydrosciences, Technische Universität Dresden - Pratzschwitzer Str. 15, 01796 Pirna, Germany

Article Info:

Received:

28 June 2019

Revised:

9 September 2019

Accepted:

19 September 2019

Available online:

26 September 2019

Keywords:

Greenhouse gas emissions

Global warming

National Inventory Reports

\begin{abstract}
The Member States of the United Nations Framework Convention on Climate Change are required to periodically publish their national inventories of anthropogenic emissions in National Inventory Reports. The data used in this paper was extracted from these reports and applied to generate a study of the development of greenhouse gas emissions in the waste management sector. The results show a reduction of greenhouse gas emissions for developed contries/regions from 1990 to 2016 due to improved collection and treatment of landfill gas, a shift from landfilling to biological and thermal treatment, as well as a shift to separate waste collection and treatment. The developing countries and regions show another development of greenhouse gas emissions. On the one hand, their greenhouse gas emissions from the waste sector strongly increased due to higher generation of waste. And on the other hand, they increased due in most cases to unorganized and technically insufficent disposal of mixed waste on dumpsites along with better observation of disposal sites and therefore better registration of emissions. Nevertheless, the per capita emissions in developed countries/regions are with approx. $500 \mathrm{~kg} \mathrm{CO}_{2}$-eq./a much higher than for developing and emerging countries/regions, which just emit around $100 \mathrm{~kg} \mathrm{CO}$-eq./a.
\end{abstract}

\section{INTRODUCTION}

The First World Climate Conference took place in 1979 in Geneva. The conclusion of this conference was that if fossil fuels continued to be depleted as before, and deforestation rates persisted, there would be a further increase of the Carbon Dioxide $\left(\mathrm{CO}_{2}\right)$ concentration in the atmosphere; and thus a warning was given out. After the Toronto Conference in 1988, where targets were set for a $20 \%$ reduction of greenhouse gas ( $\mathrm{GHG}$ ) emissions by 2005 and a $50 \%$ reduction by 2050 , the Second World Climate Conference in Geneva took place in 1990. At this conference the first progress report of the Intergovernmental Panel on Climate Change (IPCC) was reviewed, which led to the founding of the United Nations Framework Convention on Climate Change (UNFCCC). This treaty was adopted on the $9^{\text {th }}$ of May 1992 in New York and signed by 154 countries (Parties) in June 1992 at the United Nations Conference on Environment and Development (UNCED) in Rio de Janeiro. The UNFCCC came into force on the $12^{\text {th }}$ of August 1996.

Along with the ratification of this treaty "all Parties, ..., shall: develop, periodically update, publish and make available to the Conference of the Parties, ..., national inventories of anthropogenic emissions by sources and removals by sinks of all greenhouse gases not controlled by the Montreal Protocol, using comparable methodologies to be agreed upon by the conference of the Parties" (UN, 1992). These national inventories of anthropogenic emissions are published in National Inventory Reports (NIR). They include anthropogenic greenhouse gas emissions of different sectors, one of which being the waste sector. The NIR of the parties are available to the public and the data therein was used to make this overview of the global development of greenhouse gas emissions in the waste management sector.

\section{METHODOLOGY}

\subsection{UNFCCC National Inventory submissions}

The various parties which report their annual GHG-emissions to the UNFCCC can be devided into Annex I parties and non-Annex I parties. In general, Annex I parties include those countries that were members of the Organisation for Economic Co-operation and Development (OECD) in 1992 as well as countries (especially in Eastern Europe) with economies in transition (EIT Parties), whereas developing countries are considered non-Annex I parties (UNFCCC, 2006).

In accordance with the principle of "common but differentiated responsibilities and respective capabilities" the reporting requirements and timetabels are very different 
for Annex I parties and non-Annex I parties. Therefore, the extent of data available depends on whether the country is an Annex I party (which provides information annually on the amount of GHG-emissions released) or a non-Annex I party (where significant data gaps are very common) (UNFCCC, 2006).

Within the submitted reports, GHG-emissions in the form of $\mathrm{CH}_{4}$ and $\mathrm{N}_{2} \mathrm{O}$ are usually stated on their own as well as in the form of $\mathrm{CO}_{2}$-equivalents $\left(\mathrm{CO}_{2}\right.$-eq.) (IPCC, 2006). In order to enable a better comparison between the different kinds of GHG-emissions caused within the different kinds of waste streams, the following figures will show all GHG-emissions as $\mathrm{CO}_{2}$-equivalents $\left(\mathrm{CH}_{4}=25\right.$ $\mathrm{CO}_{2}$-eq. and $\mathrm{N}_{2} \mathrm{O}=298 \mathrm{CO}_{2}$-eq.) (UNFCCC, 2014). While all the data on released $\mathrm{GHG}$-emissions is originally based on the reports submitted to the UNFCCC by the various parties, most of the data used in this study is taken directly from the website of the UNFCCC. Figure 1 outlines how GHG-emissions are generally segmented in the annual reports (IPCC, 2006).

Despite being part of the Waste sector in the Figure 1, GHG-emissions of "Wastewater Treatment and Discharge" were not included in any of the subsequent figures or calculations. Furthermore GHG-emissions declared as "Other" were also excluded. Lastly, in order to give a more complete picture of the waste management sector, GHG-emissions caused by waste incineration with energy recovery were transferred from the Energy sector (where they are usually reported) to the Waste sector. While they are mostly listed separately within the parties' reports, those GHG-emissions released through the incineration of waste with energy recovery and those without energy recovery will within this study be indicated combined.

\subsection{System boundaries}

In the country reports, only direct emissions produced in a sector are presented. Indirect up- and downstream emissions are assigned to the direct emissions of the corresponding sectors. For example, the indirect upstream emissions from the transportation of waste are assigned to the transportation sector and not included in the subsequent figures. The same applies for avoided GHG-emisions e.g. by energy and secondary raw material supply. These avoided indirect downstream emissions are also not included in the inventory of the waste sector and the subsequent figures.

Figure 2 shows the decided-upon system boundary around the waste sector and which direct emissions of this sector were considered exclusively.

\subsection{Waste treatment options}

\subsubsection{Landfill and Dumpsite}

In a global context, disposal of solid waste on landfills and dumpsites represents the most common kind of waste treatment. Especially in developed countries, landfills are frequently equipped with modern technologies; such as landfill gas collection systems, which - through the installation of vertically or horizontally positioned wells - allow the collection and utilization (e.g. for the production of electricity) of the emitted landfill gas. In contrast, most developing countries tend to deposit large amounts of their solid waste on mostly illegal and non-monitored dumpsites without modern technologies that prevent GHG-emissions from entering the atmosphere (IPCC, 2007).

GHG-emissions from landfilling occur under anaerobic circumstances, caused through the presence of moisture and the lack of oxygen. Aside from the release of

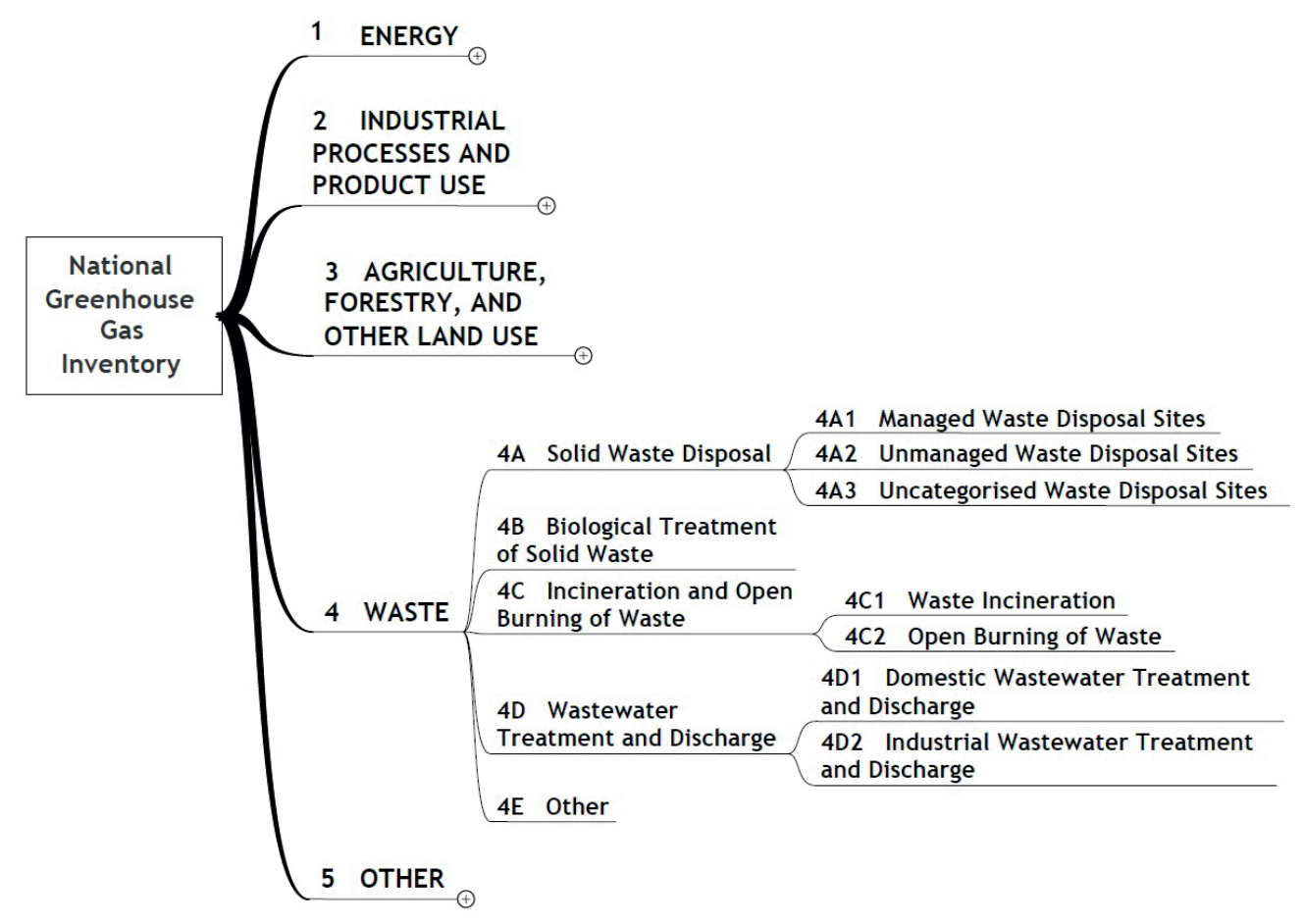

FIGURE 1: Structure of categories within the waste sector and coding of their IPCC categories (IPCC, 2006). 


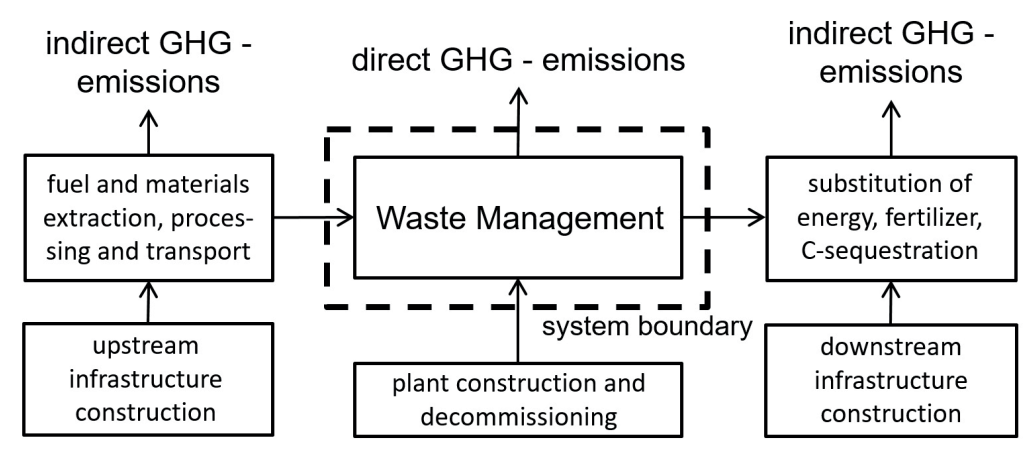

FIGURE 2: System boundary of the reported greenhouse gas emissions (own figure derived from Abu Qdais et al., 2019).

climate-damaging $\mathrm{CH}_{4}$, waste disposal also leads to the release of carbon-neutral $\mathrm{CO}_{2}, \mathrm{~N}_{2} \mathrm{O}$, and small amounts of non-methane volatile organic compounds (IPCC, 2006). Apart from the presence of a modern landfill gas collection system, the amount of degradable organic matter (and therefore the amount of bioavailable carbon) in the form of organic waste within the landfill or dumpsite plays a key role in generating GHG-emissions (EUROSTAT, 2010).

\subsubsection{Biological treatment}

Biological treatment can take place in the form of composting (aerob) or digestion (anaerob). $\mathrm{CO}_{2}$-emissions caused through biological treatment are of biogenic origin and can thus be considered carbon- and climate neutral. Climate-damaging GHG-emissions through the biological treatment of solid waste mainly occur as $\mathrm{CH}_{4}$ and $\mathrm{N}_{2} \mathrm{O}$. Even though the amount of GHG-emissions generated through the biological treatment of waste compared to the amount of GHG-emissions caused by landfilling or waste incineration in general is significantly smaller, biological treatment of waste can still have a considerable influence on the amount of total GHG-emissions within the waste sector, since the amounts of separately collected organic waste treated biologically are not deposited in landfills (IPCC, 2006).

\subsubsection{Waste incineration}

Incineration of waste is another major source of GHG-emissions in the waste management sector. Whereas clinical waste is incinerated in many countries, the incineration of municipal waste is more common in developed countries. Waste incineration means the combustion of solid and liquid waste in controlled incineration facilities. GHG-emissions released through the incineration of waste consist mainly of $\mathrm{CO}_{2}, \mathrm{~N}_{2} \mathrm{O}$, and (as a result of incomplete combustion) $\mathrm{CH}_{4}$. The $\mathrm{CO}_{2}$-emissions are in most cases much higher than $\mathrm{N}_{2} \mathrm{O}$ - and $\mathrm{CH}_{4}$-emissions. While $\mathrm{CO}_{2}$-emissions from the combustion of (partly) fossil originated waste should be included in national emissions by the parties, $\mathrm{CO}_{2}$-emissions from the combustion of biomass should not be included (IPCC, 2006).

\section{RESULTS - GREENHOUSE GAS INVENTO- RIES}

To get an overview of the development of global GHG-emissions from 1990 to 2016, the emissions from the largest contributors were analysed. These are China with approx. $27.5 \%$, the United States with approx. $14.8 \%$, India with approx. $6.4 \%$, Russia with approx. $4.9 \%$, Japan with approx. $3 \%$, Brazil with approx. $2.3 \%$, Germany with approx. $2 \%$ and Canada with approx. $1.6 \%$. These parties emit approx. $62.5 \%$ of the global emissions (based on the year 2014) (WRI, 2017).

Since the Annex I parties are required to report their emissions annually and a gapless data basis is available, these countries are analysed first. The selected non-Annex I parties are looked at separately since they do not report their GHG-inventories regulary and thus (particularly when comparing the selected larger regions) a few reasonable assumptions, oriented on the existing data, had to be made to fill in existing data gaps.

To get an even clearer picture of the development of global emissions, the larger regions of the European Union (EU28 + Iceland) with approx. 9.3\%, North America (USA, Canada and Mexico) with approx. 18\%, Russia and some of the New Independent States (Russian Federation, Kazakhstan, Uzbekistan and Ukraine) with approx. 6.9\% and Asian states (China, India, Japan, South Korea, Turkey, Saudi Arabia, Malaysia, Thailand and Vietnam) with approx. 42.6\% were analysed. These larger regions emitted $76.8 \%$ of the global GHG-emissions in 2014 (WRI, 2017). The selected states are the biggest polluters in their respective larger regions and provide the most sufficient data.

Figure 3 shows all countries and larger regions that were considered in this study on a global map.

\subsection{Selected Annex I parties}

\subsubsection{United States of America}

The United States of America is currently the second largest contributor with a relatively stable level of emissons between 6 and 7 billion $\mathrm{Mg} \mathrm{CO}_{2}$-eq. (6.356 Mg in 1990 and $6.511 \mathrm{Mg}$ in 2016 with a peak of $7.351 \mathrm{Mg}$ in 2006) generated over all sectors per year (UNFCCC, 2019).

Emissions of the waste sector decreased from approx. 188.2 million $\mathrm{Mg} \mathrm{CO}_{2}$-eq. in 1990 (2.96\% of total emissions) to approx. 122.3 million (1.88\% of total emissions) (UNFCCC, 2019). Figure 4 shows the development of GHG-emissions released by the waste sector of the United States of America between 1990 and 2016 by different disposal paths.

Since a lot of waste is still dumped and landfilled in the United States and older dumps and landfills are often not 


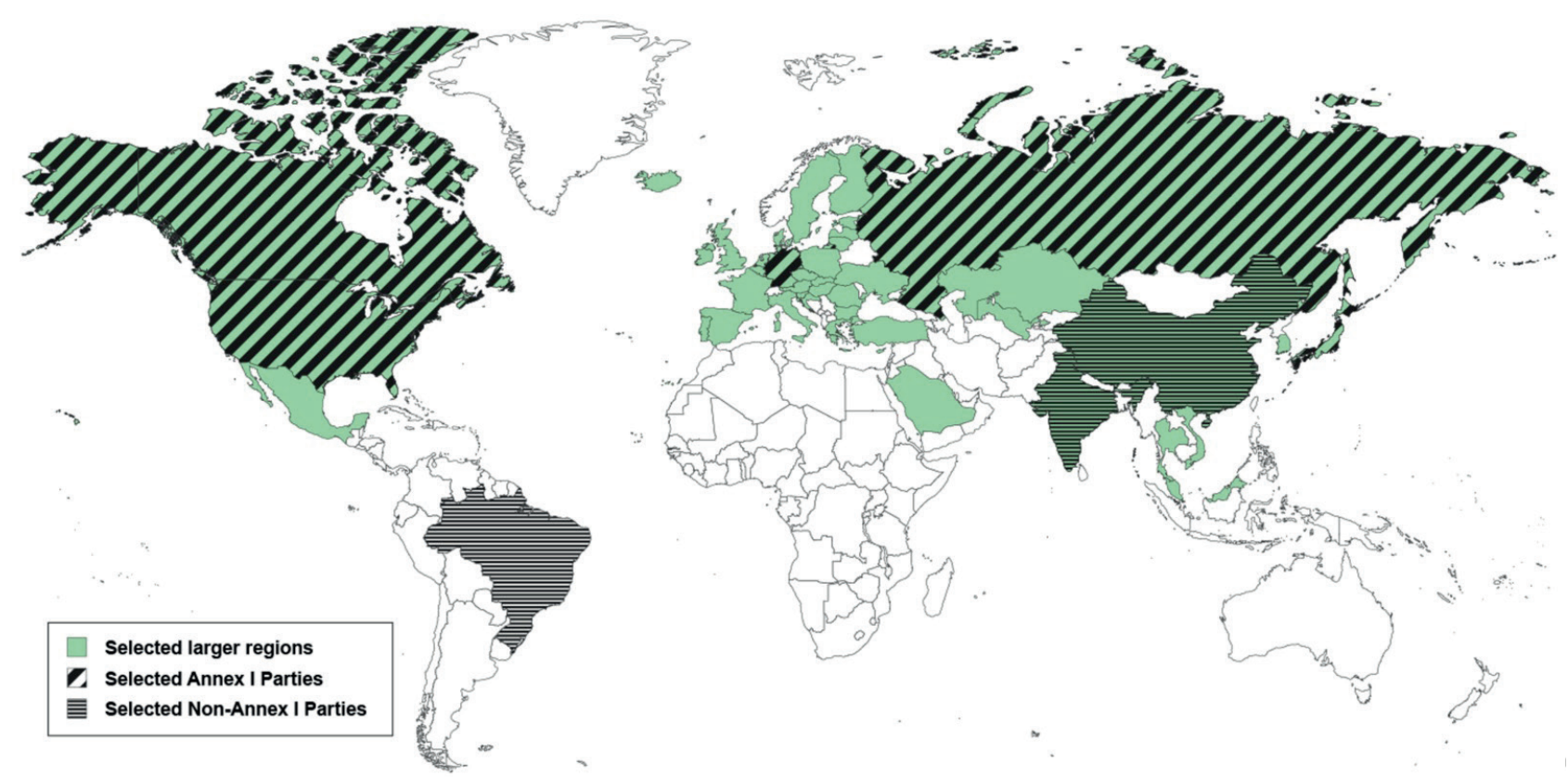

FIGURE 3: Map of the world with the considered parties/countries and larger regions (own figure).

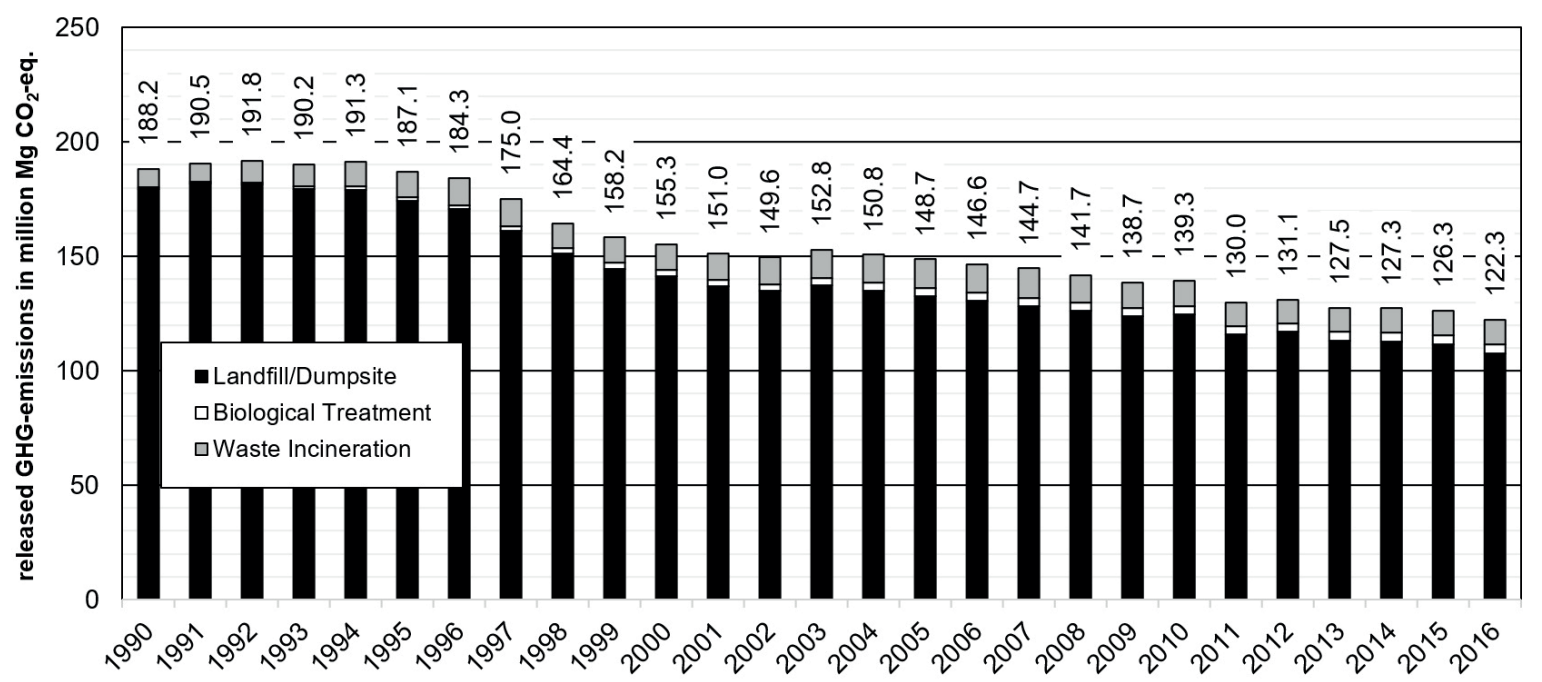

FIGURE 4: Greenhouse gas emissions released by the waste sector of the United States of America between 1990 and 2016 by disposal path (own figure derived from UNFCCC, 2019).

sufficiently equipped with landfill gas collection systems, a substantial amount of methane is produced and emitted into the atmosphere. Emissions from biological and thermal treatment of waste have increased from 1990 to 2016, however, compared to the greenhouse gases emitted from landfills and dumpsites, their contribution is far less significant (DOS, 2014).

The amount of GHG-emissions released in the US waste sector was reduced by approx. 65.9 million $\mathrm{Mg} \mathrm{CO}_{2}$-eq./a or approx. 35.00\% from the base year 1990 until 2016.

\subsubsection{Russian Federation}

The Russian Federation is the fourth largest contributor worldwide with a decrease in GHG-emissions over all sectors from approx. 3.734 billion $\mathrm{Mg} \mathrm{CO}_{2}$-eq. (1990) to 2.644 billion $\mathrm{Mg} \mathrm{CO}_{2}$-eq. (2016) (UNFCCC, 2019). A decrease to a minimum of 2.217 billion $\mathrm{Mg} \mathrm{CO}_{2}$-eq. in 1998 was due to the decline of Russian industry in the early 90's. After 1998, GHG-emissions started to rise again.

Emissions of the waste sector increased from approx. 52.0 million $\mathrm{Mg} \mathrm{CO}_{2}$-eq. in 1990 (1.39\% of total emissions) to approx. 86.8 million (3.28\% of total emissions). Figure 5 shows the development of GHG-emissions released in the waste sector of the Russian Federation between 1990 and 2016 by different disposal paths.

Almost all of the waste in the Russian Federation ends up on landfills or (in most cases) dumpsites. Some neglectable amounts of GHG-emissions (max. 70,000 $\mathrm{Mg} \mathrm{CO}$-eq. in 2012) were caused by biological waste treatment. Since a majority of waste is still dumped on 
older dumpsites or landfills, which in most cases are not equipped with landfill gas collection systems, considerable amounts of methane are emitted into the atmosphere (IFC, 2012). Some waste incineration plants are being planned for the Moscow region and Kazan (Kanunnikova, 2016), but as of 2016 no emissions from waste incineration were reported by the Russian Federation.

The amount of GHG-emissions in the Russian waste sector increased by approx. 34.8 million $\mathrm{Mg} \mathrm{CO}_{2}$-eq./a, which is approx. $67.01 \%$ from the base year 1990 until 2016.

\subsubsection{Japan}

Japan is the fifth largest contributor in terms of overall amount of GHG-emissions. Japan's total released emissons over all sectors hovered within a relatively stable range between 1.267 billion $\mathrm{Mg} \mathrm{CO}_{2}$-eq. (1990) and 1.305 billion $\mathrm{Mg} \mathrm{CO}_{2}$-eq. (2016) (UNFCCC, 2019).
GHG-emissions in the Japanese waste sector remained fairly stable from approx. 35.0 million $\mathrm{Mg} \mathrm{CO}_{2}$-eq. in 1990 ( $2.76 \%$ of total emissions) to approx. 34.6 million in 2016 (2.65\% of total emissions) (UNFCCC, 2019). Between 1994 and 2008 GHG-emissions in Japan's waste sector increased slightly to around 40 million $\mathrm{Mg} \mathrm{CO}_{2}$-eq./a. Figure 6 shows the development of GHG-emissions released by the Japanese waste sector between 1990 and 2016 by different disposal paths.

Given its high population density and the lack of available area for landfill sites, incineration of waste is the most common disposal path in Japan (Vehlow et al., 2015). Therefore GHG-emissions caused by waste incineration (which also include the emissions from gasification melting furnace) are significantly higher than those caused from landfilling waste (Nojiri et al., 2018). The rise of GHG-emissions by waste incineration/thermal treatment in the middle of the 1990s was due to the increasing Japa-

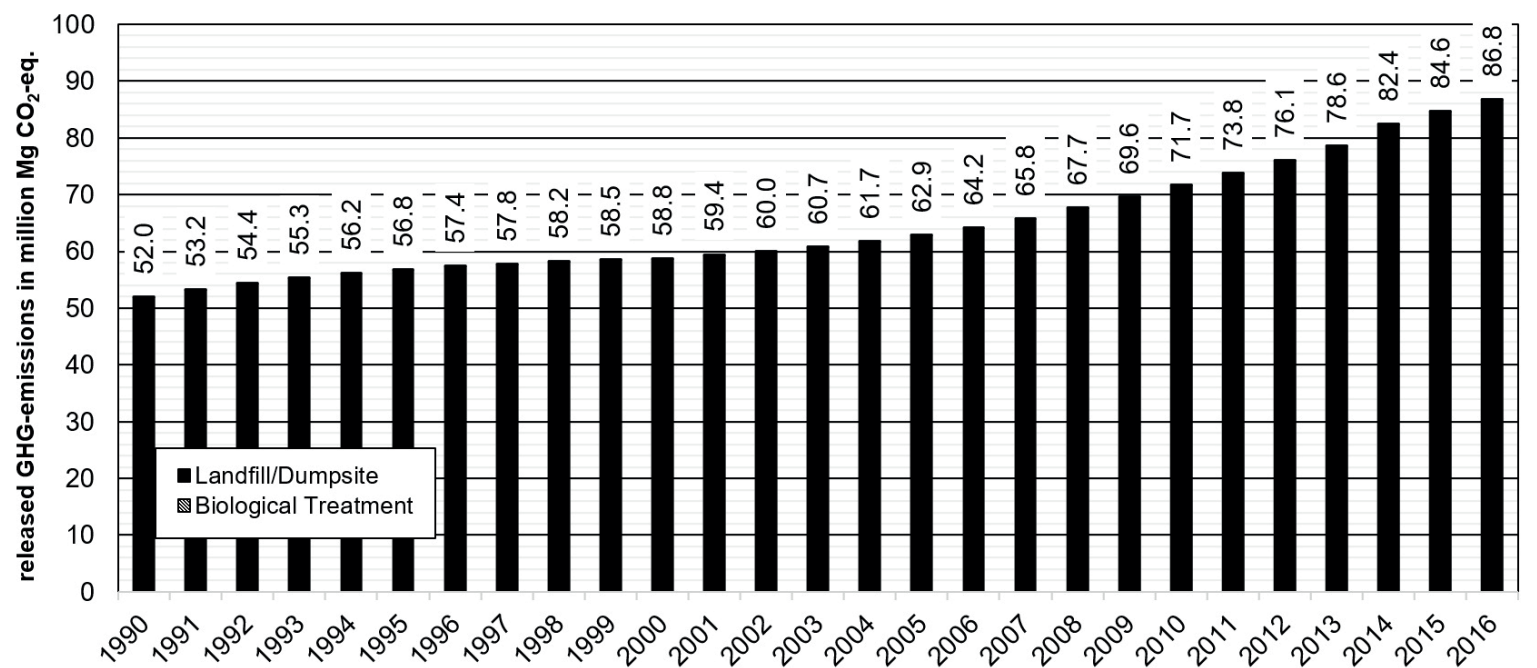

FIGURE 5: Greenhouse gas emissions released by the waste sector of the Russian Federation between 1990 and 2016 by disposal path (own figure derived from UNFCCC, 2019).

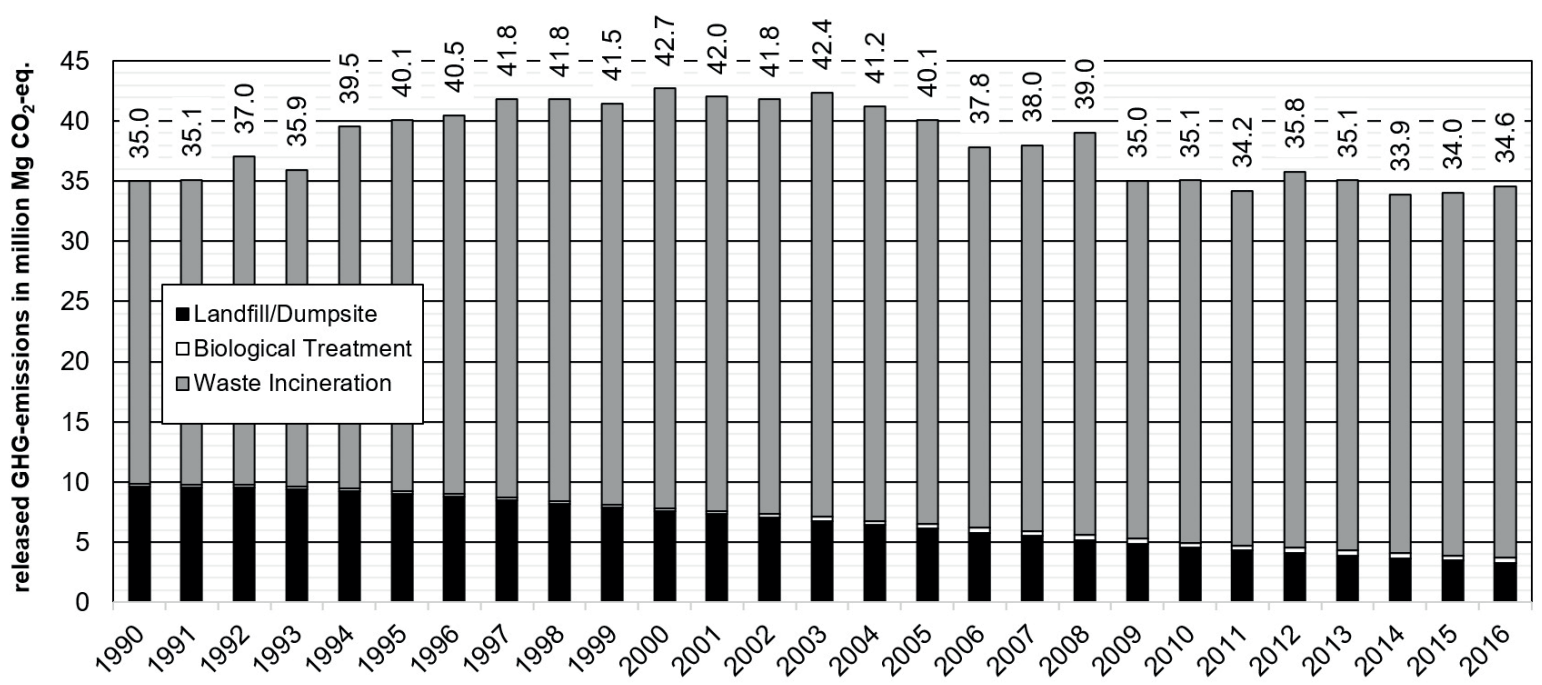

FIGURE 6: Greenhouse gas emissions released by the waste sector of Japan between 1990 and 2016 by disposal path (own figure derived from UNFCCC, 2019). 
nese economy connected with growing waste generation (MOE, 2014) and the expansion of the capacity of pyrolysis and gasification plants. Due to a national regulation at this time that required incineration ashes to be melted down, the Japanese favored two-stage/combined processes (consisting of gasification/pyrolysis combined with slag smelting) rather than incineration with downstream slag smelting (Vaccani and Asato, 2014). The decrease from 2005 - 2009 was caused by changes in the Japanese industrial structure and economy with the effect that waste generation continued to decrease as a result of progress in sorted collection, recycling and in the development of a sound material-cycle society (MOE, 2014).

The levels of GHG-emissions released by Japan's waste sector decreased by approx. 0.4 million $\mathrm{Mg} \mathrm{CO}_{2}$-eq./a or approx. 1.15\% from the base year 1990 until 2016.

\subsubsection{Germany}

As the seventh largest contributor, Germany decreased its total GHG-emissions from 1.252 billion $\mathrm{Mg} \mathrm{CO}_{2}$-eq. (1990) to 909 million $\mathrm{Mg} \mathrm{CO}_{2}$-eq. (2016) (UNFCCC, 2019).

Direct emissions in the waste sector decreased in the same range as the total emissions over all sectors, from 38.1 million $\mathrm{CO}_{2}$-eq. in 1990 (3.04\% of total emissions) to 28.7 million $\mathrm{Mg} \mathrm{CO}_{2}$-eq. in 2016 (3.16\% of total emissions) (UNFCCC, 2019). Figure 7 shows the development of GHG-emissions released by the waste sector in Germany between 1990 and 2016 by different disposal paths.

Aside from a slight increase in GHG-emissions from biological waste treatment, a shift of GHG-emissions from landfill to waste incineration took place in the German waste sector. In 1990 more than 34 million $\mathrm{Mg} \mathrm{CO}_{2}$-eq. were released by landfills and dumpsites in the form of methane. This was reduced to approx. 8 million $\mathrm{Mg} \mathrm{CO}_{2}$-eq. by 2016 . In contrast, the emissions from waste incineration increased from approx. 4 million $\mathrm{Mg} \mathrm{CO}$-eq. in 1990 to approx. 19 million $\mathrm{Mg} \mathrm{CO}_{2}$-eq. in 2016 (Gniffke and Strogies, 2018).

The extent of direct GHG-emissions released in the Ger- man waste sector was reduced by approx. 9.4 million $\mathrm{Mg}$ $\mathrm{CO}_{2}$-eq./a or approx. $24.62 \%$ from the base year 1990 until 2016.

\subsubsection{Canada}

The eighth largest contributor of GHG-emissions is Canada with an increase of total emissions released over all sectors from 603 million $\mathrm{Mg} \mathrm{CO}_{2}$-eq. (1990) to 704 million $\mathrm{Mg} \mathrm{CO}_{2}$-eq. (2016) (UNFCCC, 2019).

Emissions of the waste sector increased between 1990 and 2006 from approx. 17.7 million $\mathrm{Mg} \mathrm{CO}_{2}$-eq. to approx. 20.8 million $\mathrm{Mg} \mathrm{CO}_{2}$-eq. and then decreased back to 17.8 million $\mathrm{Mg} \mathrm{CO}_{2}$-eq. in 2016 (UNFCCC, 2019). In 1990 the waste sector accounted for $2.93 \%$ of total emissions and in 2016 for approx. 2.53\%. Figure 8 shows the development of GHG-emissions released in the waste sector of Canada between 1990 and 2016 by different disposal paths.

Most of Canada's waste is still dumped and landfilled, while older dumps or landfills are often not sufficiently updated with landfill gas collection systems. Therefore, large amounts of methane are still produced and emitted into the atmosphere. Emissions from the biological treatment of waste have increased between 1990 and 2016, but compared to the greenhouse gases emitted through disposing waste on landfills and dumpsites, their amounts are insignificant. (ECCC, 2017) GHG-emissions due to waste incineration remained relatively stable around 0.9 million $\mathrm{Mg}$ $\mathrm{CO}_{2}$-eq./a.

The level of released GHG-emissions in the Canadian waste sector could not be reduced from the base year 1990 till 2016 and increased by less than 0.1 million $\mathrm{Mg}$ $\mathrm{CO}_{2}$-eq./a or respectively approx. $0.19 \%$.

\subsection{Selected non-Annex I parties}

\subsubsection{China}

China is currently the country with the largest amount of GHG-emissions released per year. As a non-Annex I party, the data about China's GHG-emissions submitted to the

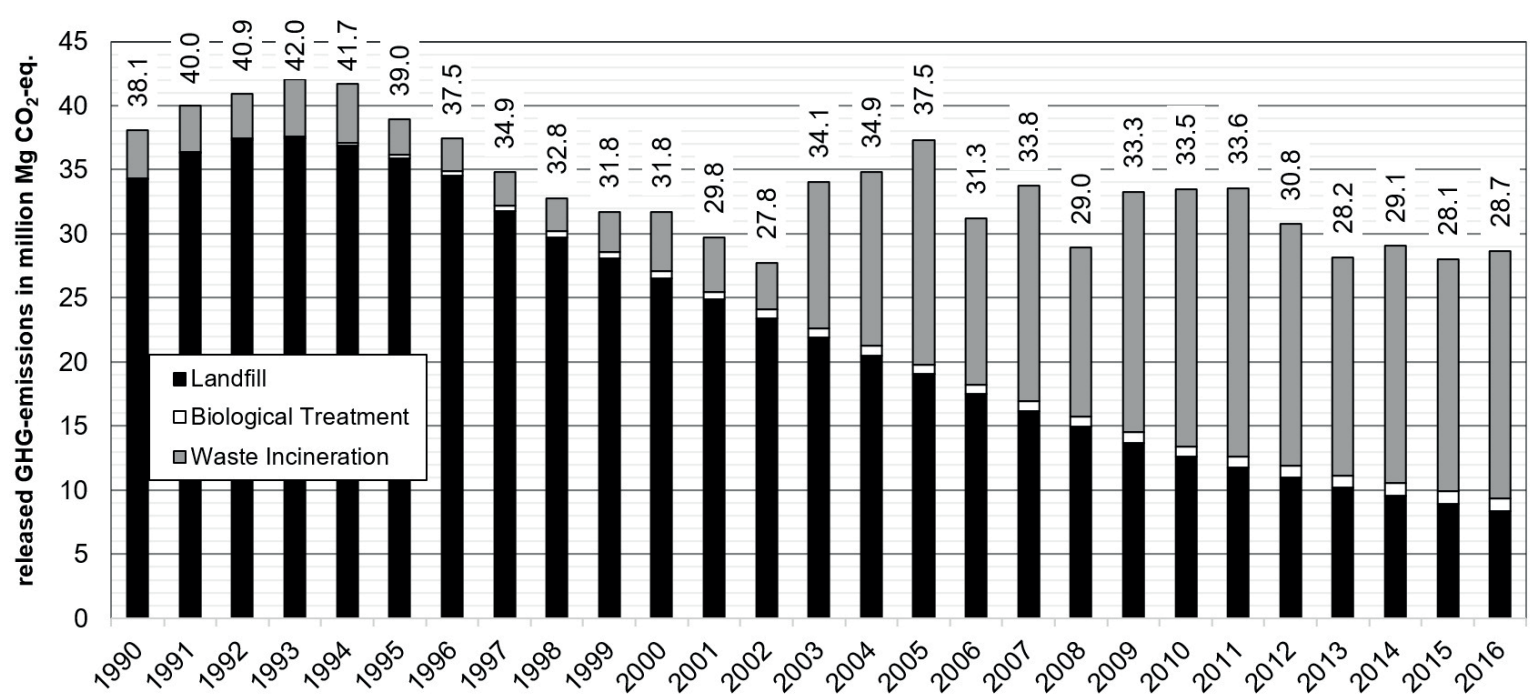

FIGURE 7: Greenhouse gas emissions released by the waste sector of Germany between 1990 and 2016 by disposal path (own figure derived from UNFCCC, 2019). 
UNFCCC has many more gaps than that of Annex I parties, and only includes the three years of 1994, 2005 and 2012. Over this period, China's total GHG-emissions almost tripled, rising from 4.058 billion $\mathrm{Mg} \mathrm{CO}_{2}$-eq. (1994) to 11.896 billion $\mathrm{Mg} \mathrm{CO}_{2}$-eq. (2012) (UNFCCC, 2019).

Within the same period, GHG-emissions in China's waste sector also showed a significant rise, climbing from approx. 42.6 million $\mathrm{Mg} \mathrm{CO}_{2}$-eq. (1994) to 67.1 million $\mathrm{Mg}$ $\mathrm{CO}_{2}$-eq. (2012) (UNFCCC, 2019). The waste sector accounted for $1.05 \%$ of China's total emissions in 1994. Even though the amount of GHG-emissions released in the waste sector increased, its share decreased to $0.56 \%$ in 2012 because of an even bigger emissions growth within the other sectors. Figure 9 shows the development of GHG-emissions released by the waste sector of China between 1994 and 2012 devided in the different disposal paths.

Despite an increase in the amount of waste incinerated over the last decades, discarding solid waste on land- fills and dumpsites remains the preferred disposal path in China (Nelles et al., 2015). Since many of the landfills or dumpsites are not sufficiently equipped with landfill gas collection systems, a considerable amount of landfill gas is produced and emitted into the atmosphere, resulting in almost $80 \%$ of GHG-emissions within the waste sector being caused by the disposal of waste on landfills or dumpsites in 2012. In China, biological treatment of waste takes place to a certain extent in the form of composting. However, China's submitted GHG data does not include this kind of treatment and it can be assumed that the amount of GHG-emissions released through biological treatment compared to those released through landfilling and waste incinceration is negligible (Li et al., 2016).

The GHG-emissions in China's waste sector therefore showed an increase between 1994 and 2012 climbing from 42.6 million to 67.1 million $\mathrm{Mg} \mathrm{CO}_{2}$-eq./a, which is approx. $57.46 \%$.

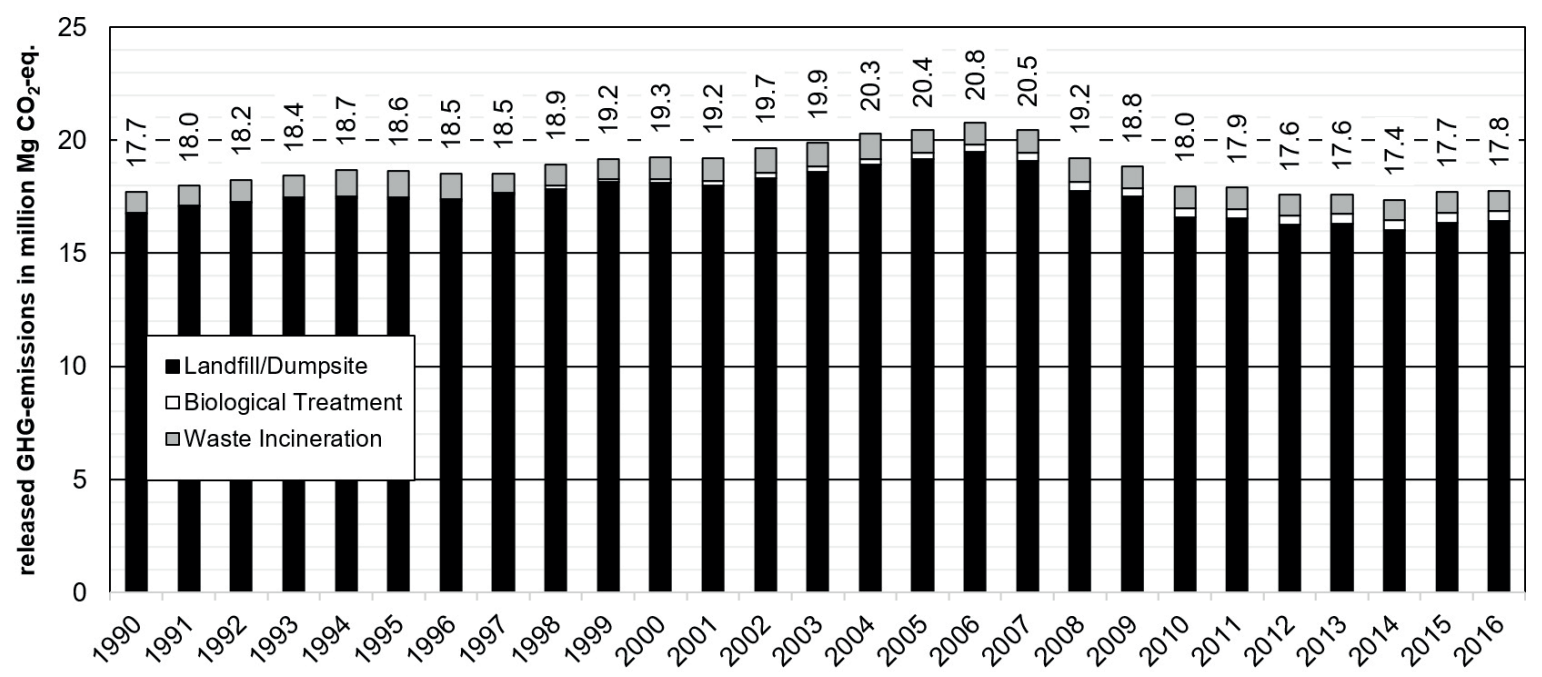

FIGURE 8: Greenhouse gas emissions released by the waste sector of Canada between 1990 and 2016 by disposal path (own figure derived from UNFCCC, 2019).

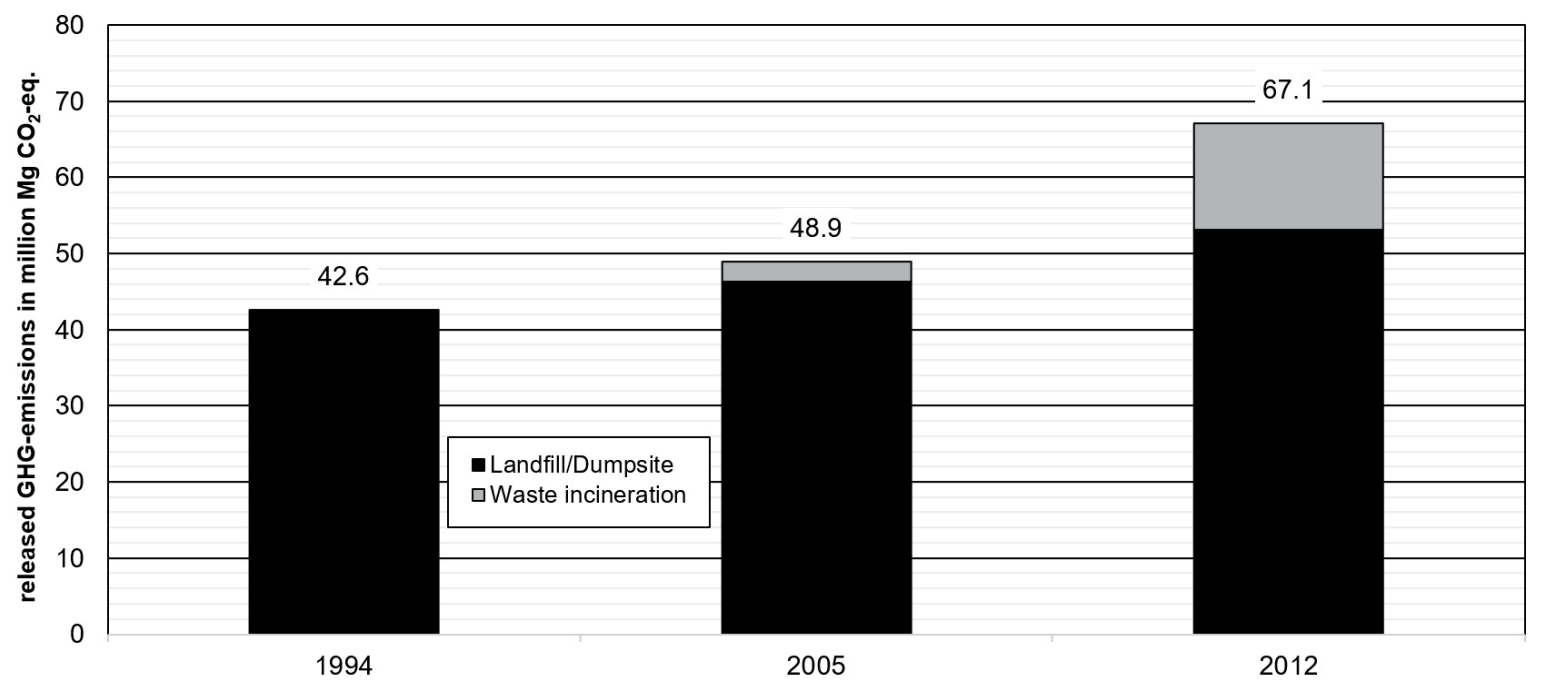

FIGURE 9: Greenhouse gas emissions released by the waste sector of China between 1994 and 2012 by disposal path (own figure derived from UNFCCC, 2019). 


\subsubsection{India}

The third largest contributor of GHG-emissions is India. The data on released GHG-emissions submitted to the UNFCCC refers to the years 1994, 2000, 2010 and 2014. Within this period, India's total GHG-emissions rose consistently from 1.214 billion $\mathrm{Mg} \mathrm{CO}_{2}$-eq. (1994) to 2.607 billion $\mathrm{Mg}$ $\mathrm{CO}_{2}$-eq. (2014) (UNFCCC, 2019).

While India's GHG-emissions within the waste sector decreased between 1994 and 2000 from 12.2 million $\mathrm{Mg}$ $\mathrm{CO}_{2}$-eq. to 10.3 million $\mathrm{Mg} \mathrm{CO}$-eq., GHG-emissions subsequently increased again to a peak value of 15.1 million $\mathrm{Mg}$ $\mathrm{CO}_{2}$-eq. in 2014 (UNFCCC, 2019). Though the total amount of released GHG-emissions in the Indian waste sector significantly rose, its share decreased over the years from $1.01 \%$ (1994) to $0.58 \%$ (2014), because similar to China there was an even stronger increase in the GHG-emissions released in the other sectors. Figure 10 shows the development of GHG-emissions released by the waste sector of India between 1994 and 2014.

Almost all the information on India's waste management refers to bigger cities, while the knowledge about rural areas of the country is very limited. Whereas an almost insignificant amount of waste seems to be composted or incinerated, a substantially larger amount is disposed of on dumpsites with no technologies installed to prevent occurring landfill gases from entering the atmosphere. Simultaneously India struggles with basic problems in their waste management, such as the lack of a nation-wide collection system for generated waste (Vogt et al., 2015).

The amount of released GHG-emissions in India's waste sector increased between 1994 and 2014 by 2.8 million Mg $\mathrm{CO}_{2}$-eq./a, which is approx. $23.26 \%$.

\subsubsection{Brazil}

Brazil is currently the sixth largest contributor in terms of total GHG-emissions released per year. Submitted data refers to all years from 1990 to 2010. Within this period, Brazil's GHG-emissions increased from 551 million $\mathrm{Mg} \mathrm{CO}_{2}$-eq. (1990) to 919 million $\mathrm{Mg} \mathrm{CO}_{2}$-eq. (2010) (UNFCCC, 2019).
In the waste sector, Brazil's GHG-emissions level steadily increased from 1990 to 2003 climbing steeply from 17.3 million $\mathrm{Mg} \mathrm{CO}_{2}$-eq. to 27.1 million $\mathrm{Mg} \mathrm{CO}_{2}$-eq., then it stabilized, reaching 27.9 million $\mathrm{Mg} \mathrm{CO}_{2}$-eq. in 2010 (UNFCCC, 2019). In 1990 the waste sector accounted for $3.14 \%$ of Brazil's total GHG-emissions. Despite a massive increase within the other sectors in 2010, the percentage of Brazil's total GHG-emissions still remained at $3.03 \%$ and hence did not show the same trend as China and India. Figure 11 shows the development of GHG-emissions released in the Brazilian waste sector between 1990 and 2010.

The reports Brazil submitted to the UNFCCC only contain information on GHG-emissions which were released through disposal of waste on landfills and dumpsites. Referring to the data of 2008, almost none (less than approx. $0.1 \%$ ) of the municipal waste generated in Brazil is treated in waste incineration facilities and only approx. $2 \%$ is recycled or composted, while at the same time almost $60 \%$ is disposed of at organized landfills and almost $40 \%$ at unorganized dumpsites (without any technologies preventing landfill gases from entering the atmosphere). This results in significant amounts of methane emissions (Kling et al., 2018).

The extent of GHG-emissions released in the Brazilian waste sector increased between 1990 and 2010 by 10.6 million $\mathrm{Mg} \mathrm{CO}_{2}$-eq./a, which is approx. $60.97 \%$.

\subsection{Selected larger regions}

\subsubsection{European Union}

The EU was able to reduce its total GHG-emissions from 5.646 billion in 1990 to 4.291 billion $\mathrm{Mg} \mathrm{CO}_{2}$-eq. in 2016 (UNFCCC, 2019). The GHG-emissions contribution of the waste sector increased from 207.4 million $\mathrm{Mg} \mathrm{CO}_{2}$-eq. in 1990 to 226.9 million $\mathrm{Mg} \mathrm{CO}_{2}$-eq. in 1995, before it began to decrease reaching 168.4 million $\mathrm{Mg} \mathrm{CO}_{2}$-eq. in 2016 (UNFCCC, 2019). The waste sector accounted for $3.67 \%$ of total emissions in 1990 and $3.92 \%$ in 2016 . Figure 12 shows the GHG-emissions in the waste sector of the EU between 1990 and 2016, devided in the different disposal paths.

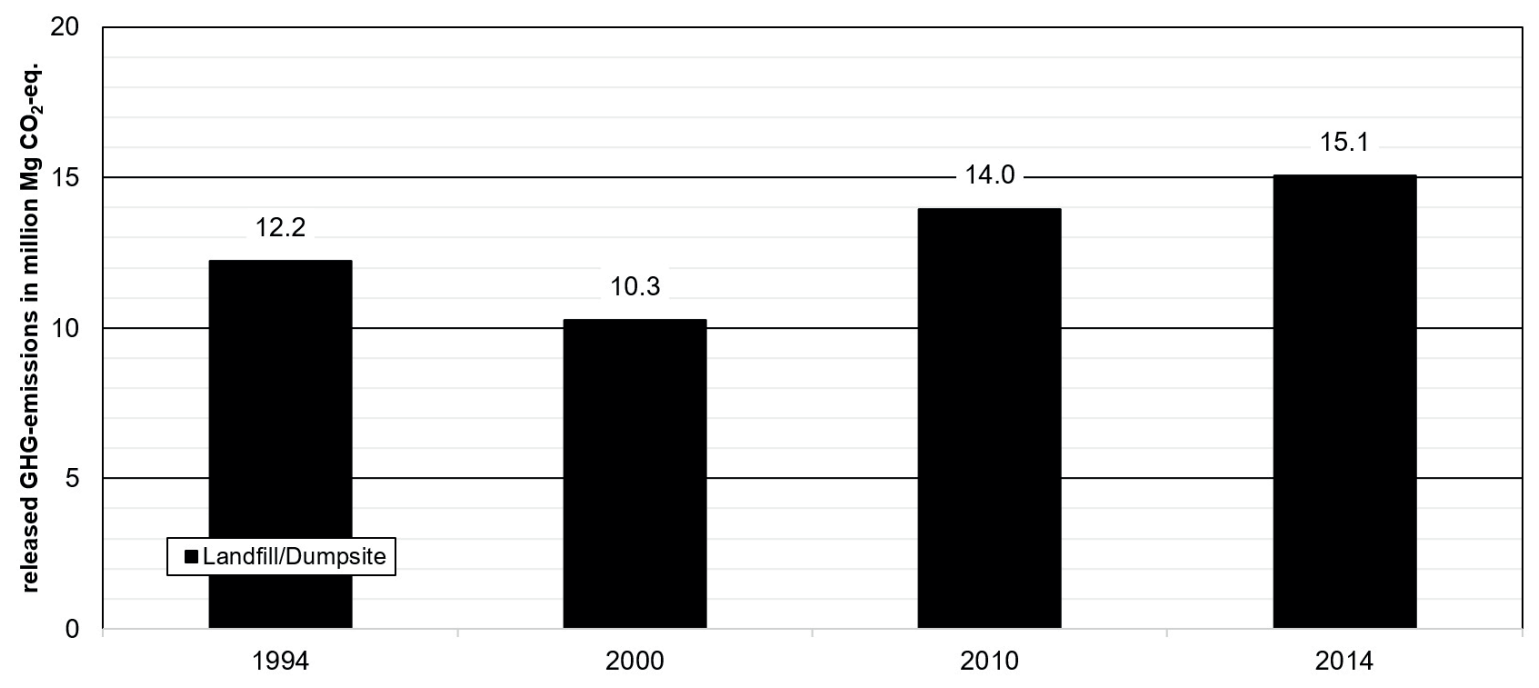

FIGURE 10: Greenhouse gas emissions released by the waste sector of India between 1994 and 2014 by disposal path (own figure derived from UNFCCC, 2019) 
Over the last decades, incineration of waste became more and more popular in the EU Member States, but this went along with a simultaneous increase in GHG-emissions. However, even in 2016, landfilling still marks the disposal path with the largest amount of released GHG-emissions at $60 \%$, while incineration covers approx. $36 \%$. The GHG-emissions caused through biological treatment of waste also increased over the last decades, but they play a minor role compared to the GHG-emissions released through landfilling or waste incineration (UNFCCC, 2019).

The level of GHG-emissions released in the EU's waste sector decreased between 1990 and 2016 by 39.1 million $\mathrm{Mg} \mathrm{CO}_{2}$-eq./a, which is approx. $18.84 \%$.

\subsubsection{North America}

The total GHG-emissions of North America (United States of America, Canada, and Mexico) increased from 7.363 billion $\mathrm{Mg} \mathrm{CO}_{2}$-eq. in 1990 to 8.707 billion $\mathrm{Mg} \mathrm{CO}_{2}$ - eq. in 2007, before it began to fall again to 7.698 billion $\mathrm{Mg} \mathrm{CO}_{2}$-eq. in 2016 (UNFCCC, 2019). In the waste sector, GHG-emissions increased from 206.5 million $\mathrm{Mg} \mathrm{CO}_{2}$-eq. in 1990 to 212.0 million $\mathrm{Mg} \mathrm{CO}_{2}$-eq. in 1994, and then decreased again to 160.7 million $\mathrm{Mg} \mathrm{CO}_{2}$-eq. in 2016 (UNFCCC, 2019). While the waste sector accounted for $2.80 \%$ of total GHG-emissions in North America in 1990, in 2016 it only accounted for $2.09 \%$. Figure 13 shows the GHG-emissions of the waste sector in North America between 1990 and 2016 by disposal path.

Disposal of waste on landfills and (especially in Mexico) dumpsites is the most common path for waste generated in the three observed countries in North America and therefore it accounts for the biggest portion of the GHG-emissions in the waste sector. While GHG-emissions released through the disposal of waste on landfills and dumpsites were able to be reduced over the last decades,

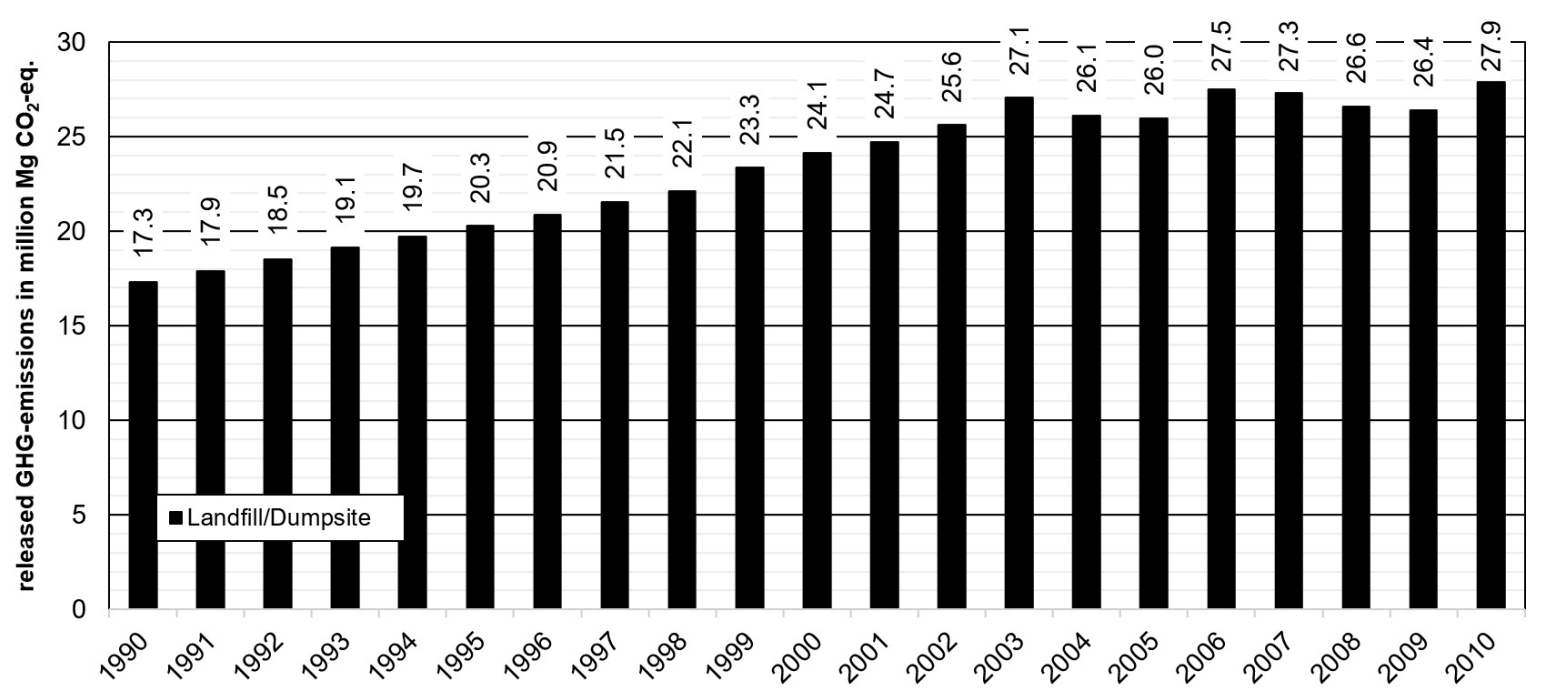

FIGURE 11: Greenhouse gas emissions released by the waste sector of Brazil between 1990 and 2010 by disposal path (own figure derived from UNFCCC, 2019).

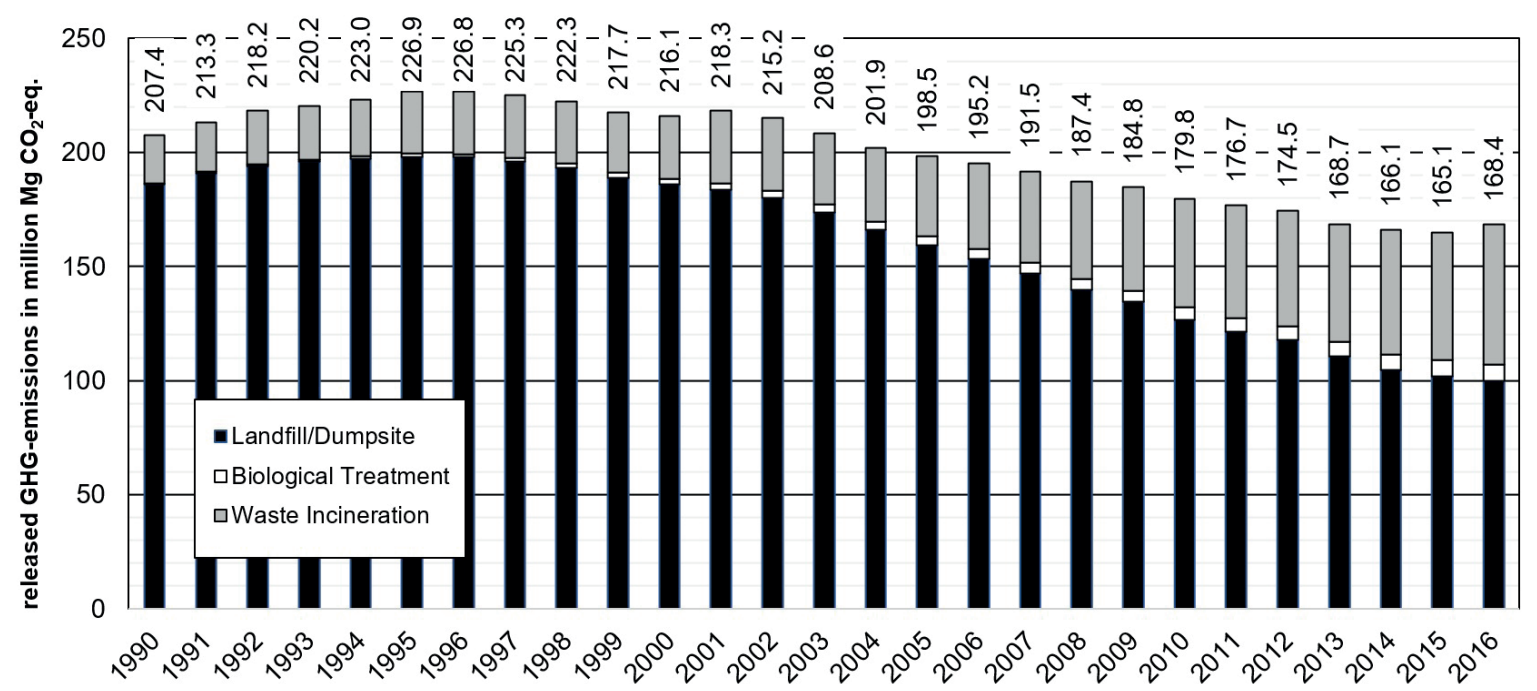

FIGURE 12: Greenhouse gas emissions released by the waste sector of the European Union between 1990 and 2016 by disposal path (own figure derived from UNFCCC, 2019) 


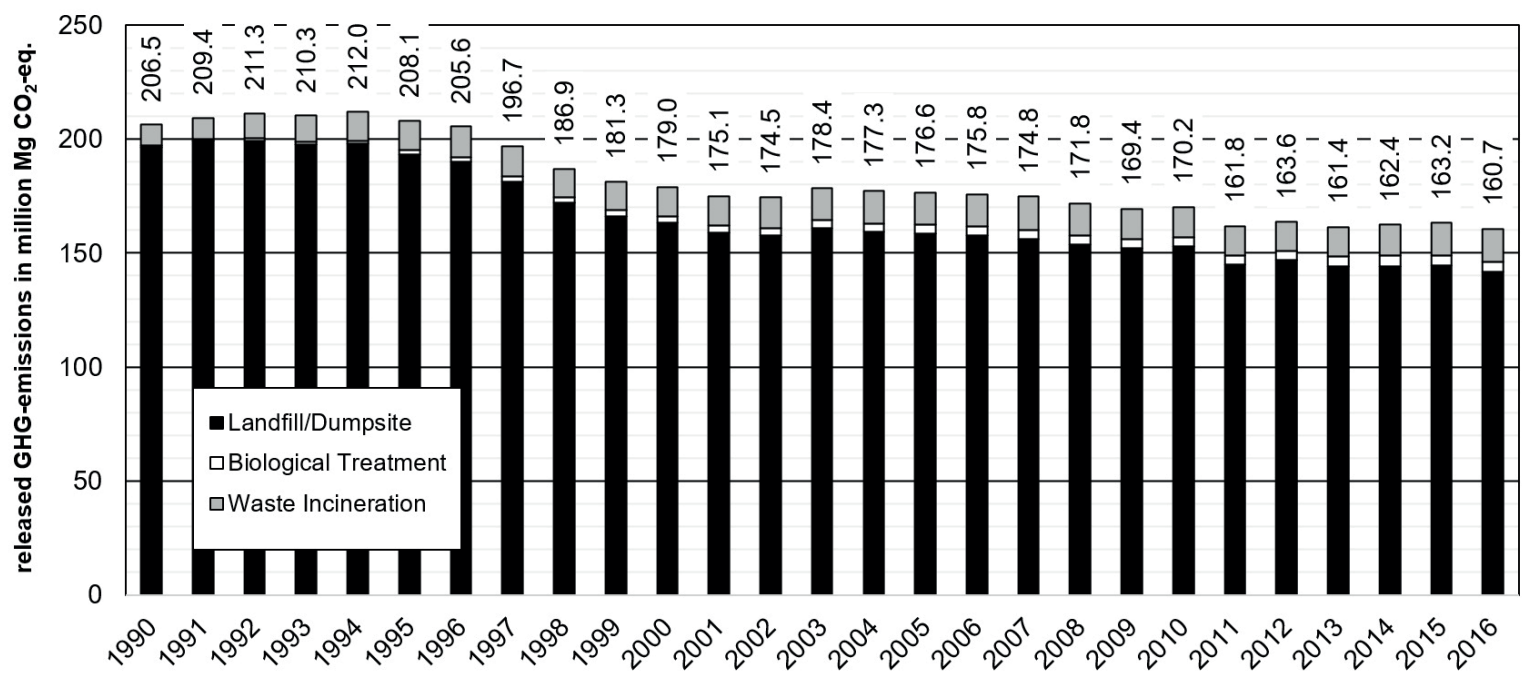

FIGURE 13: Greenhouse gas emissions released by the waste sector of North America between 1990 and 2016 by disposal path (own figure derived from UNFCCC, 2019).

those caused by waste incineration and biological treatment increased slightly (UNFCCC, 2019).

The USA accounted for the biggest part of released GHG-emissions in North America with $91.16 \%$ in 1990 and $76.04 \%$ in 2016 . While the amount of Canada's waste related GHG-emissions did not change much, Mexico's share increasedfrom0.28\%in1990to12.98\%in2013(UNFCCC,2019).

The amount of released GHG-emissions in the North American waste sector decreased between 1990 and 2016 by 45.8 million $\mathrm{Mg} \mathrm{CO}_{2}$-eq., which is approx. $22.17 \%$.

\subsubsection{Russia, Kazakhstan, Ukraine and Uzbekistan}

The total GHG-emissions of Russia and some of the Newly Independent States (NIS), Kazakhstan, Ukraine and Uzbekistan, decreased from 5.201 billion $\mathrm{Mg} \mathrm{CO}_{2}$-eq. in 1990 to 3.009 billion $\mathrm{Mg} \mathrm{CO}_{2}$-eq. in 1999. Then it increased again and stabilized at about 3.500 billion $\mathrm{Mg} \mathrm{CO}_{2}$-eq., later reaching 3.522 billion $\mathrm{Mg} \mathrm{CO}_{2}$-eq. in 2016 (UNFCCC, 2019).

In the waste sector of the observed states, GHG-emissions consistently increased from 64.0 million $\mathrm{Mg} \mathrm{CO}_{2}$-eq. in 1990 to 105.4 million $\mathrm{Mg} \mathrm{CO}_{2}$-eq. in 2016 (UNFCCC, 2019). While in $1990 \mathrm{GHG}$-emissions from the waste sector only accounted for $1.71 \%$ of the total emissions released in Russia and the observed NIS countries, they accounted for $3.99 \%$ in 2016 . Figure 14 shows the increase of GHG-emissions in Russia and the observed NIS countries between 1990 and 2016 by disposal path.

Even though biological treatment and incineration of waste exist to a certain extent, those two disposal paths accounted for only $0.17 \%$ in 1990 and $0.08 \%$ in 2016 of all GHG-emissions in the waste sector, while the remaining GHG-emissions were caused by the disposal of waste on landfills and dumpsites. In most cases these landfills and dumpsites are not equipped with landfill gas collection systems, leading to substantial amounts of methane being emitted into the atmosphere (Skryhan et al., 2018). The Russian Federation accounts for $81.18 \%$ of the released GHG-emissions in the waste sector of the four observed countries in 1990, while in 2016 it accounted for $82.37 \%$.
The growth of released GHG-emissions within the waste sector not only took place in the Russian Federation, but also in the other three contries. None of the observed countries was able to reduce its waste-related GHG-emissions.

The amount of GHG-emissions released in the waste sector of Russia, Kazakhstan, Ukraine and Uzbekistan increased between 1990 and 2016 by 41.4 million $\mathrm{Mg} \mathrm{CO}_{2}$ eq./a or approx. $64.60 \%$.

\subsubsection{Selected Asian countries}

The total GHG-emissions of selected Asian countries (including Turkey, Japan, China, India, South Korea, Saudi Arabia, Malaysia, Thailand, and Vietnam) consistently increased from 6.472 billion $\mathrm{Mg} \mathrm{CO}_{2}$-eq. in 1990 to 21.172 billion $\mathrm{Mg} \mathrm{CO}_{2}$-eq. in 2016 (UNFCCC, 2019). The GHG-emissions in the waste sector of these selected Asian countries also consistently increased from 124.4 million $\mathrm{Mg} \mathrm{CO}_{2}$-eq. in 1990 up to 219.6 million $\mathrm{Mg} \mathrm{CO}_{2}$-eq. in 2016 (UNFCCC, 2019). Even though they consistently increased, GHG-emissions of the waste sector accounted only for $1.04 \%$ of total emissions in 2016, while in 1990 they had accounted for $1.92 \%$. This is mainly because of the even more rapid growth of GHG-emissions within other non-waste sectors. Figure 15 shows the GHG-emissions in the waste sector of the selected Asian countries between 1990 and 2016 by disposal path.

As can be seen in the Figure 15, GHG-emissions in the waste sector can largely be attributed to the disposal of waste on landfills and dumpsites, which accounted for $78.31 \%$ of released emissions in 1990 and $73.22 \%$ in 2016. Since in many of the observed countries landfills and dumpsites are not sufficiently equipped with landfill gas collection systems, serious amounts of methane are emitted into the atmosphere (Modak et al., 2017). Waste incineration in some of the observed countries is getting more and more popular as there was an increase to $26.57 \%$ of GHG-emissions in the waste sector in 2016, compared to $21.49 \%$ in 1990 . Remaining GHG-emissions were released through biological treatment of waste and seem to be neg- 


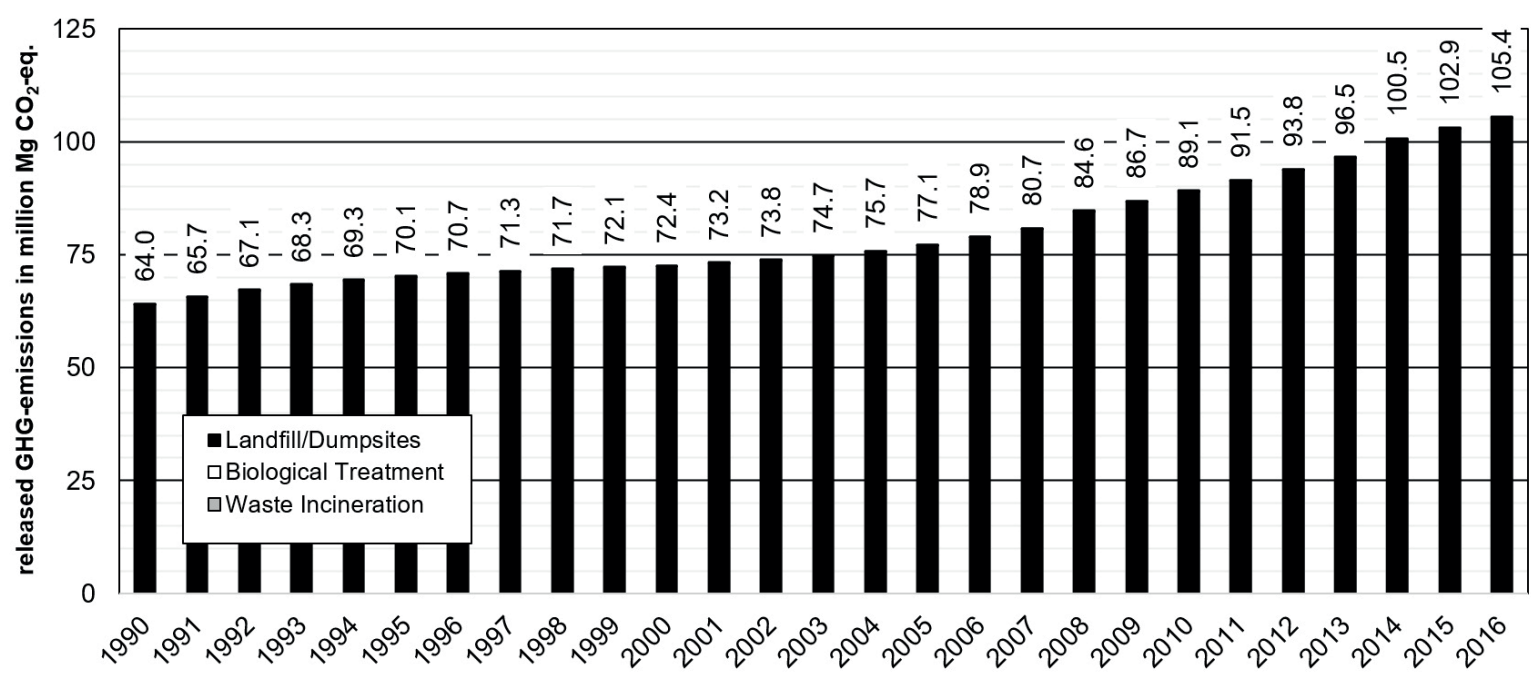

FIGURE 14: Greenhouse gas emissions released by the waste sectors of Russia, Kazakhstan, Ukraine and Uzbekistan between 1990 and 2016 by disposal path (own figure derived from UNFCCC, 2019).

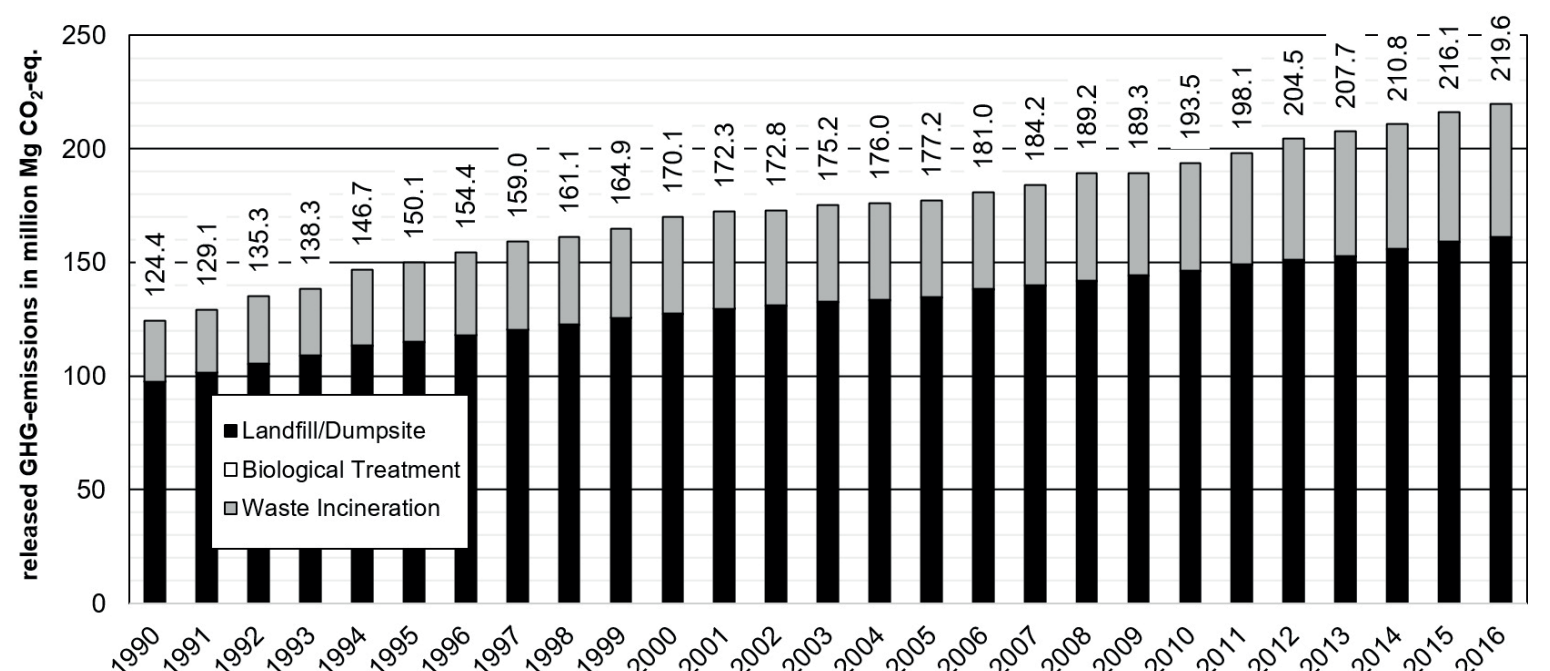

FIGURE 15: Greenhouse gas emissions released by the waste sector in selected Asian countries between 1990 and 2016 by disposal path (own figure derived from UNFCCC, 2019).

ligible in comparison with the other disposal paths.

China accounted for $31.05 \%$ of waste-related GHG-emissions in 1990 , followed by Japan with $28.13 \%$. When combined, South Korea, Saudi Arabia, Thailand, Vietnam and Malaysia accounted for $28.70 \%$ in 1990 . In 2016, China was still accountable for $35.52 \%$ of the released GHG-emissions in the waste sector, while Japan only contributed $15.75 \%$ and the five smaller states $35.98 \%$.

The GHG-emissions in the waste sector of the selected Asian countries increased between 1990 and 2016 by 95.2 million $\mathrm{Mg} \mathrm{CO}_{2}$-eq./a or approx. $76.53 \%$.

\subsection{Summary}

\subsubsection{Selected parties}

The disposal path responsible for the largest amount of released GHG-emissions in the waste sector is for the majority of the observed countries disposal of waste on landfills or dumpsites. Germany and Japan are the exception by having the incineration of waste as the greatest source of released GHG-emissions. Even though Canada, the United States, and China are reporting about released GHG-emissions through waste incineration, those amounts are much smaller compared to emissions caused through the disposal of waste within each respective country. In Russia, India and Brazil, nearly all released GHG-emissions in the waste sector can be traced back to the disposal of waste on landfills and dumpsites. Figure 16 shows the GHG-emissions caused in the waste sectors of the observed countries in the base year (1990 for Annex I parties and Brazil, 1994 for China and India) and the year with the latest available data (2016 for Annex I parties, 2010 for Brazil, 2012 for China and 2014 for India). In addition to the total values, Figure 16 also shows the GHG-emissions converted to "per capita" values for each country in the respective year.

The United States is the leading contributor of GHG-emissions in the waste sector in the base year, as 


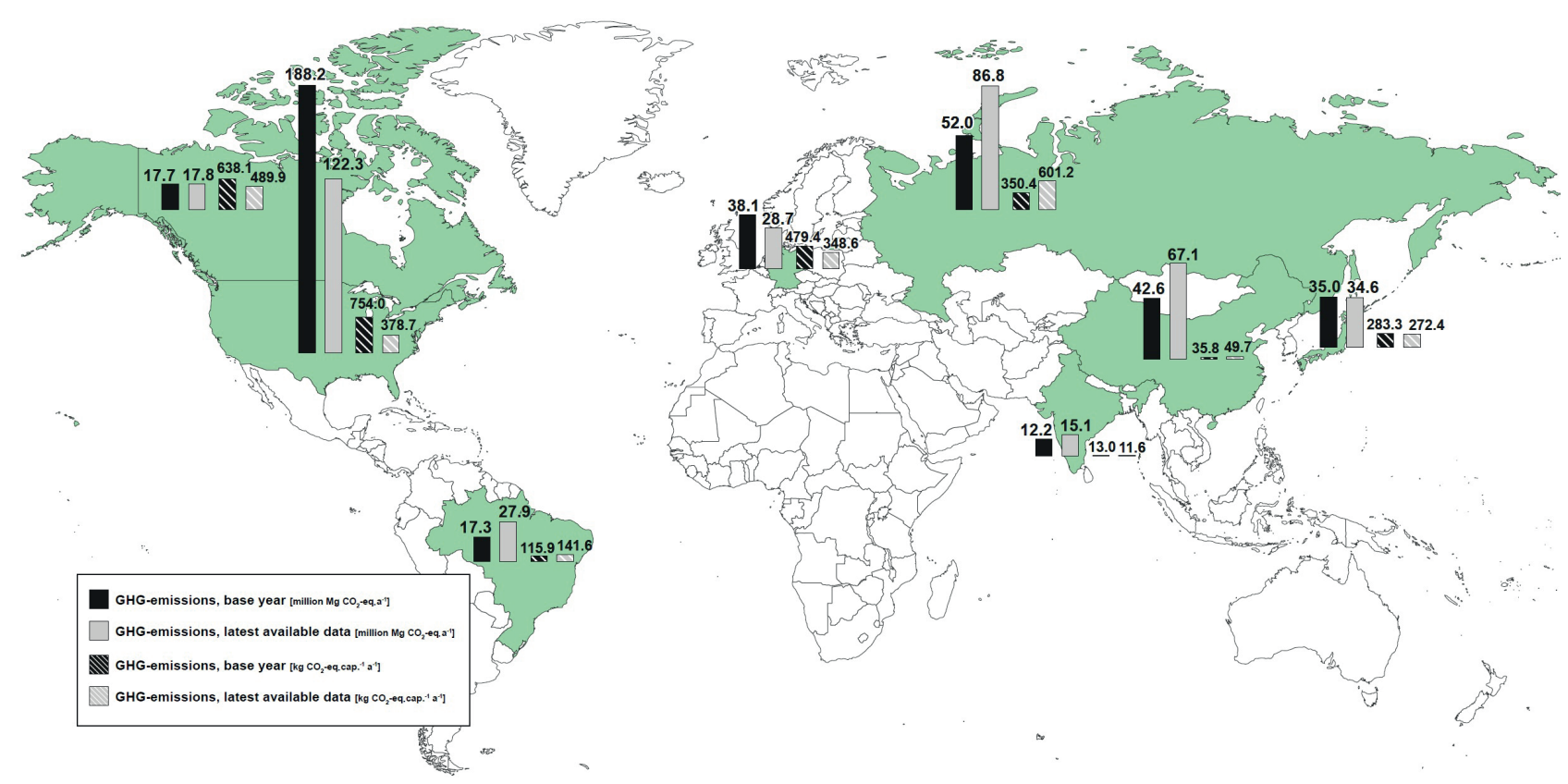

FIGURE 16: Greenhouse gas emissions released by the waste sector in the observed countries in the base year and the year with the latest available data (own figure derived from UNFCCC, 2019).

well as the year with the latest available data; followed by the Russian Federation and China. While only one of the five observed Annex I parties (the Russian Federation) showed a clear increase in waste-related GHG-emissions, two others (Canada and Japan) remained almost constant and another two (Germany and the United States) showed a clear decrease over the observed period. Meanwhile the GHG-emissions in the waste sectors of all three observed non-Annex I parties clearly changed for the worse.

Interestingly, the GHG-emissions per capita give another picture. With the very sizeable population of the observed non-Annex I parties, their GHG-emissions per capita are much smaller than those of the Annex I parties. In the year with the latest available data, Brazil accounted for ap-

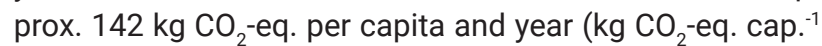
$\left.\mathrm{a}^{-1}\right)$, China for $50 \mathrm{~kg} \mathrm{CO}$-eq. cap.- ${ }^{-1} \mathrm{a}^{-1}$ and India for only 12 kg CO${ }_{2}$-eq. cap.- ${ }^{-1} \mathrm{a}^{-1}$. Russia, Canada and the United States released the biggest amounts of GHG-emissions per capita (with approx. 601, 490 and $379 \mathrm{~kg} \mathrm{CO}_{2}$-eq. cap. ${ }^{-1} \mathrm{a}^{-1}$ respectively), followed by Germany and Japan (with 349 and 272 kg CO 2 -eq. cap.- ${ }^{-1} \mathrm{a}^{-1}$.

\subsubsection{Selected larger regions}

Within the larger regions, positive developments could be observed for the EU (168.4 million $\mathrm{Mg} \mathrm{CO}_{2}$-eq. in 2016) and North America (160.7 million $\mathrm{Mg} \mathrm{CO}_{2}$-eq. in 2016); with the EU's GHG-emissions level being slightly above that of North America in 1990 as well as in 2016. Meanwhile, Russia, Kazakhstan, Ukraine and Uzbekistan (105.4 million Mg $\mathrm{CO}_{2}$-eq. in 2016) along with the selected Asian countries (219.6 million $\mathrm{Mg} \mathrm{CO}_{2}$-eq. in 2016) showed significant increases in GHG-emissions released in the waste sector, with the selected Asian countries even clearly surpassing both the EU and North America in 2016. Figure 17 shows the GHG-emissions caused in the waste sectors of the observed larger regions in 1990 and 2016. In addition to the total values, Figure 17 shows the GHG-emissions converted to "per capita"-values for each one of the observed larger regions in 1990 and 2016.

By having huge populations, the observed Asian coun-

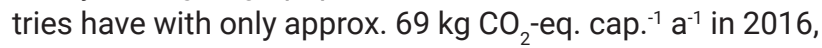
much lower per-capita emissions than those of the other three larger regions. While Russia, Kazakhstan, Ukraine and Uzbekistan show the greatest amounts of released GHG-emssions per capita in the waste sector in 2016 (approx. 440 kg CO${ }_{2}$-eq. cap.- ${ }^{-1} \mathrm{a}^{-1}$ ), North America and the EU have similar amounts, both being around $330 \mathrm{~kg} \mathrm{CO}_{2}$-eq. cap..$^{-1} a^{-1}$.

\section{DISCUSSION}

In a global context (Figures 16 and 17), the GHG-emissions caused through the disposal of waste on landfills and dumpsites clearly seem to be responsible for the largest amount of GHG-emissions released in the waste sector. This is not surprising, since the global warming factor of $\mathrm{CH}_{4}$ related to $\mathrm{CO}_{2}$ is 25 and even the best equipped landfills cannot catch all of the generated landfill gas.

In particular, the observed Annex I countries show different approaches and efforts on how to reduce the kinds of emissions from landfills and dumpsites. In Germany the disposal of waste containing biodegradable material on landfills was legally prohibited, which lead to considerably smaller amounts of biodegradable waste (which is a key factor for the amounts of generated landfill gas) ending up on German landfills (Gniffke and Strogies, 2018). Many other European Countries (e.g. Austria, Belgium, Czech Republic, Denmark, Netherlands, United Kingdom) charge landfill taxes for wastes containing biodegradable material 


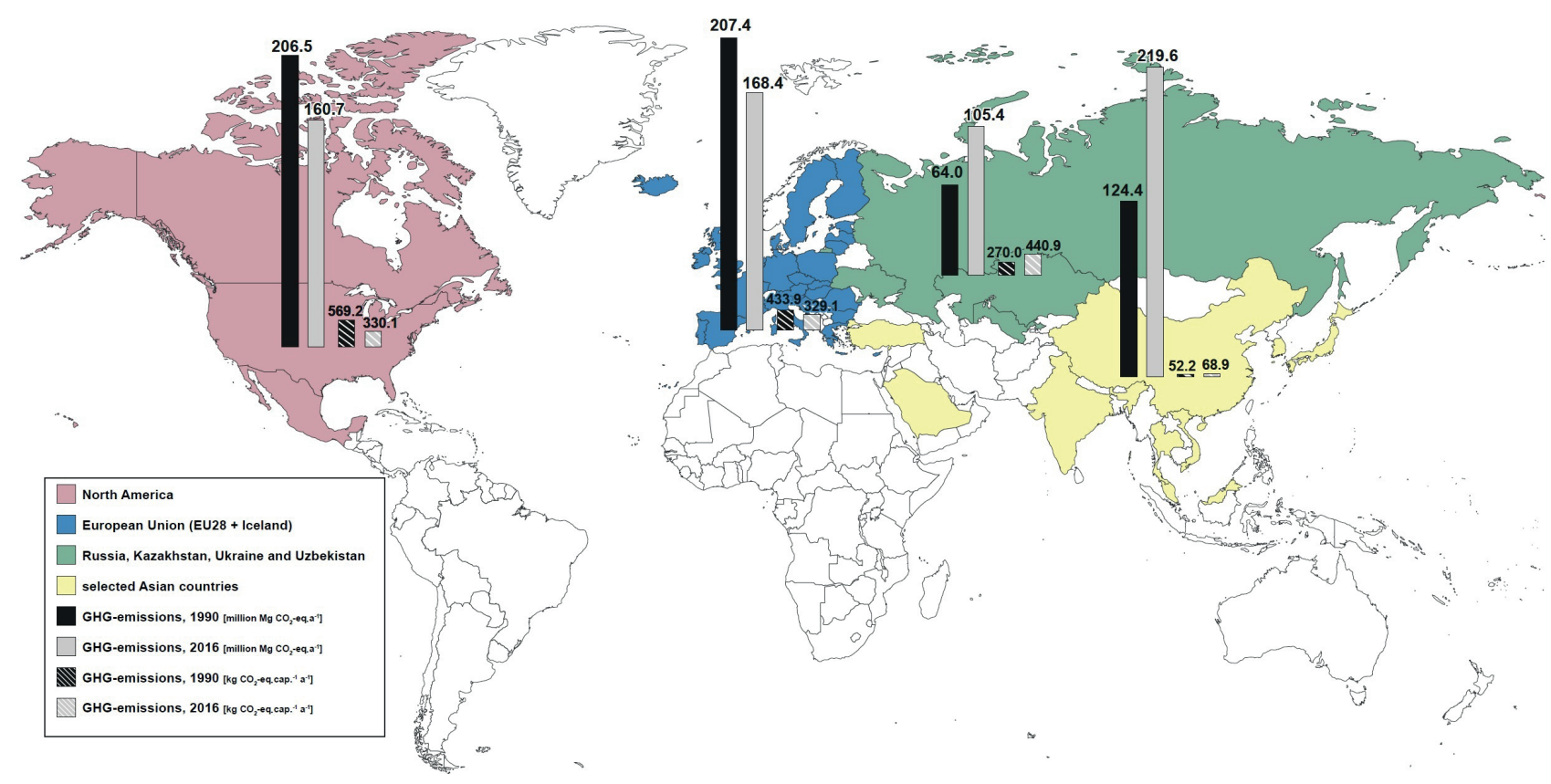

FIGURE 17: Greenhouse gas emissions released by the waste sector in the observed larger regions in 1990 and 2016 (own figure derived from UNFCCC, 2019).

to prevent the disposal of such waste on landfills (Paleari et al., 2012). Although disposing biodegradable material is prohibited (since 2005 in Germany) or strongly reduced by high landfill taxes (in some other European countries), those countries still report landfill-related GHG-emissions, since landfill gas is generated even many years after the deposition of biodegradable material.

Although the reduction of organic material being landfilled seems to be the most promising method to reduce GHG-emissions from landfills, many countries (especially developed ones) try to prevent methane emissions from reaching the atmosphere by installing landfill gas collection systems. Through the installation of horizontal or vertical wells, the generated gas is collected to a certain degree and can either be used to produce energy or just be flared to convert $\mathrm{CH}_{4}$ to $\mathrm{CO}_{2}$. However, in many cases (for example in the United States and Canada) only landfills of a certain size must be equipped with this kind of technology, while on smaller landfills without landfill gas collection systems, the generated gas continues to escape into the atmosphere (DOS, 2017) (ECCC, 2017). Meanwhile, in quite a few of the less developed countries, which are struggling with basic problems in their waste sectors (e.g. the non-existence of a nation-wide waste collecting system, often in rural parts of the country), huge amounts of waste are discarded on unorganized dumpsites with no serious efforts to prevent deposition of organic material and a general lack of state of the art technologies, such as landfill gas collection systems (IFC, 2017) (Vogt et al., 2015).

These observations can also be made in the progression of the waste-related GHG-emissions in the different observed countries. The GHG-emissions through landfilling in the United Stated decreased to a lesser extent than in Germany, as the focus in the USA is on collecting and us- ing the generated landfill gas, while Germany prevents the disposal in the first place. On the other hand, emissions of the Russian Federation increased because there are many landfills and dumpsites which are not adequately equipped with state of the art technology.

Municipal solid waste in developed countries contains larger amounts of carbon, which is fixed in plastics, composite materials, textiles and papers, and in lesser amounts as easily bioavailable carbon in food waste. When this waste is disposed on well-managed landfills where the waste is kept relatively dry, bioactivity is reduced, and thus only small amounts of biogenic carbon are converted to landfill gas and larger amounts of carbon are sequestrated in the landfill. When in addition, large quantities of the generated landfill gas are collected and treated, relatively small amounts of GHG-emissions are released to atmosphere. As a result, the performance of well-managed and equipped landfills in terms of GHG-emissions released into the atmosphere can be better than that of the waste incineration process (Wünsch and Bilitewski, 2011). This is also demonstrated by the presented data. In the US, the majority of waste is landfilled and the specific GHG-emissions are around $0.48 \mathrm{Mg} \mathrm{CO}_{2}$-eq./Mg generated waste for 2015 (126.3 million Mg CO 2 -eq./a and $262.4 \mathrm{Mg} / \mathrm{a}$ generated (US EPA, 2018)). In Germany, significant amounts of waste are incinerated and the specific GHG-emissions are around $0.56 \mathrm{Mg} \mathrm{CO}_{2}$-eq./Mg generated waste for 2015 (28,7 million $\mathrm{Mg} \mathrm{CO}_{2}$-eq./a and $51.6 \mathrm{Mg} / \mathrm{a}$ generated (BMU, 2018)). However, it must be emphasized that landfills are constructions with limited lifetimes. Someday the surface cover will break and water will penetrate the landfill body. Then the biodegradation of sequestrated organic carbon will immediately start, and landfill gas will be produced and emitted into atmosphere. 
Even though the amount of GHG-emissions released through incineration of waste in a global context is still relatively small compared to that released by landfilling, incinceration became more and more popular over the last decades (especially in developed countries) and therefore was responsible for increasing amounts of released GHG-emissions. In Germany and Japan it even represents the disposal path with the largest amount of GHG-emissions. However, it should be noted, that GHG-emissions caused through landfilling and through waste incineration should not be evaluated the same way, since the incineration of waste has the key advantage of being able to use the energy content of not only the biological but also fossil bound carbon, while during landfilling only the biologically bound part of the carbon can be used (and that only if the necessary technology is available). In addition, landfilling comes with the disadvantage of only being able to produce energy from the amount of landfill gas that is effectively captured, while there is always a portion of non-collected gas which escapes into the atmosphere. This means that even if both disposal paths under certain circumstances are able to produce energy, in the end, incineration of waste proves to be the more effective and thus more sustainable method of waste treatment.

The increase of emissions from biological waste treatment is a result of more treated biodegradable waste and the implementation of more and more biogas plants for the anaerobic treatment of biowaste. GHG-emissions from biological waste treatment originate from fugitive $\mathrm{CH}_{4}$ and $\mathrm{N}_{2} \mathrm{O}$. Small amounts of $\mathrm{CH}_{4}$ are emitted when anaerobic conditions occur while the composting process takes place in open windrows without collecting and treating occurring emissions. $\mathrm{CH}_{4}$ is also released during anerobic digestion; e. g. during the entry and exit of material in the digester or when the digestate is transferred from the digesters to the digestate storage. (Cuhls et al., 2015) $\mathrm{N}_{2} \mathrm{O}$ can be emitted from biofilters (Jensen et al., 2017). Since the specific GHG-emissions per Mg of treated biodegradable material are relatively low, the total emissions are also low; even when considerable amounts of biodegradable waste are biologically treated.

Finally, it should be pointed out once more that the increase in GHG-emissions in non-Annex I states is also due to better quality and more well-registrated waste disposal sites (especially in rural areas), as well as the consideration of the corresponding emissions in recent reports.

\section{CONCLUSIONS}

The development of direct GHG-emissions among various contries and larger regions differs strongly dependening on national or regional economic status. Industrial countries and regions implement technical and organisational measures to reduce their GHG-emissions in the waste management sector, whereas developing and emerging countries generate more and more waste, which is in most cases simply dumped on dumpsites or on landfills equipped with inferior technology. However, the per capita GHG-emissions in particular show that there is still a wide range between approx. $500 \mathrm{~kg} \mathrm{CO}_{2}$-eq./a for de- veloped contries/regions and much less than $100 \mathrm{~kg} \mathrm{CO}_{2}$ eq./a for developing and emerging countries.

Examples of developed states/regions show that a reduction of GHG-emissions in the waste sector is possible with the implementation of well-managed and equipped landfills, which keep the landfill body dry and collect and treat most of the generated landfill gas. The problem with this waste management practice is the sequestration of organic carbon and the resulting greenhouse gases generated and then emitted in the future when the landfill cover construction breaks, water penetrates in the landfill, and micro organisms start decomposing organic material. Similar or even better results can be gained when landfill bans or high landfill taxes for biodegradable materials are implemented, and more waste is incinerated or otherwise thermally treated.

A shift to separate collection and treatment of different waste types, especially biowaste, brings the best results in terms of GHG-emissions reduction in the waste sector.

Finally, it should be highlighted that by recovering energy (especially by thermal waste treatment) and secondary raw materials (through separate waste collection and treatment), significant amounts of GHG-emissions can be avoided (e.g. Wünsch and Simon, 2018; Bilitewski and Wünsch, 2017; Dehoust et al., 2010). This is due to the substitution of energy, which is usually at least partly generated out of fossil fuels, and the substitution of primary raw materials. Their extraction is usually much more energy extensive than the production of secondary raw materials from waste.

\section{REFERENCES}

Abu Qdais, H., Wünsch, C., Dornack, C., \& Nassour, A. (2019). The Role of Solid Waste Composting in Mitigating Climate Change in Jordan. in Waste Management \& Research, 1-10, June 2019, doi. org/10.1177/0734242X19855424

Bilitewski, B. \& Wünsch, C. (2017). WTE, Greenhouse Gas Benefits. in Encyclopedia of Sustainability Science and Technology, Meyers, Robert A. (ed.), ISBN 978-1-4939-2493-6

BMU (2018) Waste Management in Germany 2018 - Facts, data, diagrams. Bundesministerium für Umwelt, Naturschutz und nukleare Sicherheit, Berlin, Germany

Cuhls, C., Mähl, B., \& Clemens, J. (2015). Ermittlung der Emissionssituation bei der Verwertung von Bioabfällen, Texte 39/2015, Umweltbundesamtes, Dessau-Roßlau, Germany

Dehoust G., Schüler, D., Vogt, R., \& Giegrich, J. (2010). Climate Protection Potential in the Waste Management Sector Examples: Municipal Waste and Waste Wood. Texte 61/2010, Umweltbundesamt, Dessau Roßlau, Germany

DOS (2017). United States Department of State (DOS). United States Climate Action Report 2014 (First Biennial Report and Sixth National Communication of the United States of America under the United Nations Framework Convention on Climate Change)

ECCC (2017). Canada's Seventh National Communication on Climate Change and Third Biennial Report - Actions to meet commitments under the United Nations Framework Convention on Climate Change. Evironment and Climate Change Canada (ECCC). Gatineau, ISBN 978-0-660-23785-5

EUROSTAT (2010). Using official statistics to calculate greenhouse gas emissions - A statistical guide. Baudouin, L., Fernandez, R., Gikas, A., Hass, J., Janowska A., Kitou, E., Moll, S., Mozes, C., Noreland, J., Piirto, J., Enescu, R., Nikolaos, R., Tavoularidis P. and Wieland, U. (eds.). ISBN 978-92-79-14487-5

Gniffke, P., \& Strogies, M. (2018). National Inventory Report for the German Greenhouse Gas Inventory 1990 - 2016. Climate Change 12/2018, Umweltbundesamt, Dessau-Roßlau, Germany 
IFC (2017). Municipal Solid Waste Management: Opportunities for Russia. International Finance Cooperation, World Bank Group. Moscow/Washington

IPCC (2006). 2006 IPCC Guidelines for National Greenhouse Gas Inventories, Prepared by the National Greenhouse Gas Inventories Programme, Eggleston H.S., Buendia L., Miwa K., Ngara T. and Tanabe K. (eds.). Published: IGES, Japan, ISBN 4-88788-032-4

IPCC (2007). Mitigation. Contribution of Working Group III to the Fourth Assessment Report of the Intergovernmental Panel on Climate Change. B. Metz, O.R. Davidson, P.R. Bosch, R. Dave, L.A. Meyer (eds.), Cambridge University Press

Jensen, M. T., Moeller, J., Moenster, J., \& Scheutz, C. (2017). Quantification of greenhouse gas emissions from a biological waste treatment facility. Waste Management Volume 67,375-384. https//doi. org/10.1016/j.wasman.2017.05.033

Kanunnikova, T. (2016). Five incineration plants to be built in the Moscow region and Tatarstan by 2025 . In Construction Russian online Journal

Kling, M., Baldauf, M., Böttger, S., \& Nöh, C. (2018). Länderprofil zur Kreislauf- und Wasserwirtschaft in Brasilien. uve GmbH für Managementberatung in cooperation with German RETech Partnership and German Water Partnership (eds.). Berlin, Germany

Li, X., Zhang, C., Li, Y., Zhi, Q. (2016). The Status of Municipal Waste Incineration (MSWI) in China and its Clean Development. in Energy Procedia, Volume 104, 498-503. https://doi.org/10.1016/j. egypro.2016.12.084 Modak, P., Pariatamby, A., Saedon, J., Bhada-Tata, P., Borongan, G., Thawn, N., \& Lim, B. (2017). ASIA Waste Management Outlook. United Nations Environment Programme, Economy Division, International Environmental Technology Centre

Nelles, M., Dorn, T., Wang, Y., Xu, A., \& Morschek, G. (2015). State of waste management in the PR China. In Müll und Abfall Journal 4/2015, Berlin, Germany

Nojiri, Y., Hatanaka, E., Oda, T., Osako, A., Ito, H. Kosaka, N., Yanagawa, M., Hayashi, A., Tanaka, A., \& Yoshinaga, H. (2018). National Greenhouse Gas Inventory Report of Japan 2018. National Institute for Environmental Studies. Tsubuka, Japan

Paleari, S., Fischer, C., Junker, H, Mazzanti, M., Wuttke, J., \& Zoboli, R. (2012). Transboundary shipments of waste in the European Union. Reflections on data, environmental impacts and drivers
Skryhan, H., Shilova, I., Khandogina, O., Abashyna, K., \& Chernikova, O. (2018). Waste Management in Post-Soviet Countries: How far from the EU?. in detritus - Multidisciplinary Journal for Waste, Resources \& Residues, Volume 03 - 2018

UN (1992). United Nations Framework Convention on Climate Change. FCCC/INFORMAL/84. GE.05-62220 (E) 200705.

UNFCCC (2006). United Nations Framework Convention on Climate Change: Handbook. Produced by Intergovernmental and Legal Affairs, Climate Change Secretariat. Blobel, D., Meyer-Ohlendorf, N., Schlosser, C., Steel, P. (eds). ISBN: 92-9219-031-8, Bonn, Germany,

UNFCC (2014). Report of the Conference of the Parties on its nineteenth session - Addendum - Part two: Action taken by the Conference of the Parties at its nineteenth session

US EPA (2018) National Overview: Facts and Figures on Materials, Wastes and Recycling. https://www.epa.gov/facts-andfigures-about-materials-waste-and-recycling/national-overview-facts-and-figures-materials (accessed September 2019)

Vaccani A. \& Asato S. (2014). Internationale Märkte für alternative Verfahren und Strategien der wichtigsten Marktteilnehmer. in Strategie, Planung, Umweltrecht, ISBN 978-3-944310-25-1, Neuruppin, Germany

Vehlow, J., Seifert H., \& Eyssen R. (2015). Structural Changes in Japan's Waste Management. In Müll und Abfall Journal 5/2015Berlin, Germany

Vogt., R., Dehoust, G., Merz, C., Radde, C., Sieck, M., \& Schwetje, A. (2015). Climate protection potential of waste management, Part 2 - India and Egypt. In Müll und Abfall Journal 6/2015, Berlin, Germany

WRI 2017. CAIT Climate Data Explorer. 2017. Washington, DC: World Resources Institute.

Wünsch, C. \& Bilitewski B. (2011). Comparison of greenhouse galances between dumping, sanitary landfilling and incineration of resisual waste. in Proceedings SARDINIA 2011 Symposium: "XIII International Waste Management and Landfill Symposium", ISBN 9788862650007, S. Margherita di Pula (Cagliari), Italy

Wünsch, C., \& Simon, F.-G. (2018). The Reduction of Greenhouse Gas Emissions Through the Source-Separated Collection of Household Waste in Germany. in The Handbook of Environmental Chemistry, Vol. 63, 269-290, ISBN 978-3-319-69071-1, Heidelberg, Germany 